\title{
STF e Constituição policy-oriented ${ }^{1}$
}

\author{
STF and policy-oriented constitution
}

\author{
Rogério Bastos Arantes ${ }^{2}$ \\ Universidade de São Paulo (São Paulo, SP, Brasil) \\ ORCID: https://orcid.org/0000-0002-7167-864X \\ E-mail: rarantes@usp.br
}

\section{Resuimo}

Este artigo analisa os efeitos de uma Constituição policy-oriented sobre o controle constitucional das leis. Baseado em evidências inéditas relativas a ações diretas de inconstitucionalidade ajuizadas no STF entre 1988 e 2015, o argumento central é que a combinação de uma Constituição policy-oriented e um sistema de judicial review de amplo acesso a atores sociais e políticos acarreta não apenas uma intensa participação do STF na política governamental - por via da revisão constitucional das políticas públicas judicializadas - como estimula o emendamento frequente da Constituição. Por meio da Metodologia de Análise Constitucional, o artigo analisa de modo integrado os dois principais mecanismos responsáveis pela mudança e pela estabilidade constitucionais - emendamento e judicial review -, oferecendo uma visão global da política constitucional brasileira. $\mathrm{O}$ artigo conclui que tais mecanismos têm funcionado de modo complementar e não antagônico, num país que decidiu fazer de sua Constituição policy-oriented um instrumento de governo, em torno da qual os três poderes, os atores políticos e os entes federativos interagem.

\section{Palavias-chave}

Supremo Tribunal Federal; Constituição policy-oriented; Controle de constitucionalidade; Emendas constitucionais; Política constitucional.

\footnotetext{
${ }^{1}$ ARANTES, Rogério Bastos. STF e Constituição policy-oriented. Suprema: revista de estudos constitucionais, Brasília, v. 1, n. 1, p. 299-342, jan./jun. 2021.

${ }^{2}$ Professor do Departamento de Ciência Política da Universidade de São Paulo. Doutor em Ciência Política. Currículo Lattes: https://lattes.cnpq.br/6438633094553520.
} 


\section{Sumário}

1. Introdução. 2. Ciência política e o estudo das Constituições: mecanismos que favorecem a mudança e a estabilidade constitucionais. 3. A Constituição de 1988 e seu emendamento frequente: governando com uma Constituição policy-oriented. 4. O STF e o controle constitucional de políticas públicas. 5. Conclusão.

\section{Abstract}

This article analyzes the effects of a policy-oriented constitution on the constitutional control of laws. Based on new-found data relating to Direct Actions of Unconstitutionality filed in the Supreme Court between 1988 and 2015, the central argument is that the combination of a policy-oriented constitution and a judicial review system with broad access to social and political actors entails not only an intense STF participation in government policy - through the constitutional review of judicialized public policies - but also encourages the frequent amendment of the constitution. Through the Methodology of Constitutional Analysis, the paper examines in an integrated way the two main mechanisms responsible for constitutional change and stability - amendment and judicial review -, offering a global view of Brazilian constitutional politics. The article concludes that such mechanisms have functioned in a complementary and not antagonistic way, in a country that decided to turn its policy-oriented Constitution into an instrument of government, around which the three branches, the political actors and federative entities interact.

\section{Keywords}

Brazilian Federal Supreme Court; Policy-oriented constitution; Judicial review; Constitutional amendments; Constitutional politics.

\section{Contents}

1. Introduction. 2. Political Science and the study of constitutions: mechanisms for improvement of change and constitutional stability. 3. The 1988 Constitution and its frequent amendment: governing with a policy-oriented constitution. 4. The STF and the constitutional control of public policies. 5. Conclusion. 


\section{Introdução}

O objetivo deste artigo é analisar os efeitos de uma Constituição policyoriented sobre a política constitucional no Brasil, especialmente seu impacto sobre a revisão judicial das leis levada a cabo pelo Supremo Tribunal Federal (STF). ${ }^{3}$ Por ter constitucionalizado diversos dispositivos de policy, a Carta de 1988 tem produzido consequências importantes, ao longo de três décadas de vigência. A primeira é que a constitucionalização original de políticas públicas obrigou os governantes a atuarem no marco constitucional para poder implementar seus programas de governo. A segunda é que governos necessitam construir amplas maiorias legislativas para fazer frente à regra de emendamento constitucional e, assim, alterar as políticas públicas constitucionalizadas. Em terceiro, o Congresso Nacional seguiu constitucionalizando novas políticas públicas após 1988, provavelmente como forma de submeter o Executivo (que não tem poder de veto sobre emendas constitucionais), o Judiciário (reduzindo margens de veto por meio do controle constitucional das leis) e a Federação (reduzindo as chances dos entes subnacionais de se desviarem da policy definida pela União) à sua vontade. Desse modo, a Constituição não apenas cumpre seu papel clássico de subordinar os atores políticos e institucionais às suas regras e princípios, mas se converte ela mesma em instrumento de governo em meio às relações entre poderes e no interior da Federação. Por fim, mas não menos importante, esse tipo especial de Constituição tem impacto significativo sobre o funcionamento do Judiciário e especialmente sobre seu órgão de cúpula - o STF -, que passam a ser acionados para controlar a constitucionalidade das leis e atos normativos, nem sempre relativos a princípios constitucionais fundamentais, mas frequentemente a políticas públicas constitucionalizadas. Desse modo, o STF participa diretamente, e bem mais do que cortes constitucionais de outros países, do processo de policy-making.

O presente trabalho retoma estudos anteriores que trataram dessas consequências, mas se concentra principalmente na apresentação de evidências inéditas capazes de dimensionar esta última: o impacto da Constituição policy-oriented sobre o controle constitucional exercido pelo STF. O exame das relações entre o perfil da Constituição

\footnotetext{
${ }^{3}$ Essa é uma das frentes de pesquisa de projeto mais amplo intitulado "Constitucionalismo e Democracia em perspectiva comparada", coordenado por mim e por Cláudio Gonçalves Couto, a quem agradeço pela parceria profícua de vários anos. Aproveito para agradecer também os pesquisadores do JUDE - Grupo de Estudos Judiciário e Democracia do DCP/USP - pela troca de ideias e, particularmente, pelo auxílio na produção de parte significativa dos dados. Versões preliminares deste artigo foram discutidas nos encontros da Associação Nacional de Pós-Graduação e Pesquisa em Ciências Sociais (ANPOCS) e da rede de pesquisa Mare Incognitum: desafios da pesquisa empírica sobre o Supremo Tribunal Federal, que coordeno juntamente com Diego Werneck Arguelhes. Os encontros anuais e a colaboração permanente dessa rede de pesquisadores têm feito avançar a agenda de pesquisa sobre o Tribunal, na qual se insere esse trabalho. Agradeço a todas e todos pelas críticas e sugestões, reservando exclusivamente a mim a responsabilidade pelas falhas remanescentes.
} 
(incluindo seu emendamento posterior) e a revisão judicial das leis nos permitirá integrar dimensões quase sempre separadas pela ciência política brasileira em busca da compreensão mais global de nossa política constitucional. Por política constitucional, entende-se "toda atividade do sistema político que tem a Constituição como objeto e particularmente aquela que resulta em alterações constitucionais, seja pelo emendamento formal, seja por interpretação judicial dos tribunais” (ARANTES; COUTO, 2019, p. 36).

Os dados inéditos aqui apresentados decorrem da aplicação da Metodologia de Análise Constitucional (MAC) no exame das ações diretas de inconstitucionalidade julgadas pelo STF. A MAC, que vem sendo desenvolvida desde estudos anteriores em parceria com Cláudio Gonçalves Couto (ARANTES; COUTO, 2008, 2009, 2010, 2012; COUTO; ARANTES, 2006, 2008), se notabiliza por dois aspectos: primeiro, ela permite distinguir, no interior do texto constitucional, princípios constitucionais de dispositivos que veiculam políticas públicas; segundo, ela permite planilhar textos constitucionais e de emendas na forma de dispositivos, codificá-los e contabilizálos. Desse modo, é possível construir a base empírica da política constitucional brasileira, da Constituição original ao seu emendamento e agora as ações de controle constitucional pelo Supremo, interligando as instâncias normativas pelas quais surgem, são renovados e disputados os elementos constitucionais. A intenção é, portanto, completar o caminho da política constitucional e reforçar a centralidade da Constituição na relação entre os poderes e na política democrática brasileira contemporânea, ampliando nosso conhecimento sobre ela.

O argumento central a ser desenvolvido é que a combinação de uma Constituição policy-oriented e um sistema de controle direto de constitucionalidade das leis de amplo acesso a atores sociais e políticos (ARANTES, 1997, 2013) faz do caso brasileiro um exemplo não só de intensa participação do judiciário na política governamental - por via da revisão constitucional das políticas públicas judicializadas - como de uma Constituição muito emendada por decorrência justamente das relações entre os poderes e entre os entes federativos.

Outra contribuição pretendida diz respeito ao estudo de mudanças constitucionais. A maioria dos trabalhos sobre o tema elege o grau de dificuldade das regras de emendamento como variável explicativa das taxas de reformas constitucionais em diferentes países. Todavia, os estudos comparativos que tomam tais regras como variável independente não chegaram a resultados conclusivos acerca da incidência do emendamento. Uma mesma regra pode levar a taxas diferentes, assim como taxas semelhantes são produzidas a partir de regras diferentes. $O$ presente artigo argumenta que umas das razões da inconsistência dos achados diz respeito à interação do 
emendamento constitucional com o controle constitucional das leis. Embora alguns estudos procurem incluir essa variável em seus modelos explicativos, nenhum deles foi capaz de especificar teoricamente a direção esperada da causalidade envolvendo a existência de algum tipo de controle constitucional das leis e a taxa de emendamento.

Além desta introdução, o artigo conta com três seções e conclusão. Na próxima, são apresentadas as principais linhas de interesse da ciência política pelas Constituições, destacando os estudos mais recentes sobre mudança e estabilidade dos textos constitucionais. A seguinte apresenta a Metodologia de Análise Constitucional (MAC) e os resultados de sua aplicação sobre o texto original da Constituição de 1988 e sobre o emendamento constitucional nessas três décadas, com destaque para o conceito de Constituição policy-oriented. Em seguida, são apresentados os resultados inéditos da aplicação da MAC ao conjunto de ações diretas de inconstitucionalidade propostas no STF entre 1988 e 2015, e são discutidas as principais hipóteses levantadas ao longo do texto. A conclusão retoma os principais aspectos desenvolvidos no artigo, com ênfase para a dimensão alcançada pela política constitucional na democracia brasileira.

\section{Ciência política e o estudo das Constituições: mecanismos que favorecem a mudança e a estabilidade constitucionais}

A ciência política desenvolveu pelo menos dois tipos de interesse pelas Constituições. O primeiro diz respeito ao papel que Constituições cumprem em regimes políticos. Nesse campo, o debate normativo é antigo e se concentrou nas relações entre Constituição e democracia, embora recentemente venha se interessando também pela função que Constituições cumprem em regimes autoritários (GINSBURG; SIMPSER, 2014). A questão clássica e central diz respeito ao papel liberal e contramajoritário das Constituições em regimes baseados na soberania popular (ELSTER; SLAGSTAD, 1988). Em que pese ter havido, historicamente, certa convergência entre constitucionalismo e democracia - de tal modo que hoje apenas os estados democráticos são capazes de proteger as liberdades, e apenas onde estas são efetivas é que o método democrático pode funcionar adequadamente (BOBBIO, 1990) - o fato de a questão de fundo permanecer aberta inspira a continuidade do bom debate. Por que atar as próprias mãos ou por que escravizar as gerações futuras por meio de uma Constituição (HOLMES, 1988)? Por que delegar poder a cortes constitucionais, que exercerão papel contramajoritário, ou a quem interessa um regime do tipo juristocracy (HIRSCHL, 2004)? Para ficarmos num exemplo sintomático da controvérsia: Jon Elster, célebre autor desse campo, elaborou a teoria da Constituição como mecanismo de autorrestrição em seu clássico Ulysses and the Sirens (ELSTER, 
1984) - no qual popularizou a metáfora de que a Constituição confere segurança à democracia assim como as amarras ao mastro garantiram a Ulysses a travessia na Odisseia - para anos mais tarde, em Ulysses Unbound (ELSTER, 2000), minimizar aquela ideia e assumir que políticos, na maioria das vezes, usam Constituições para impor sua vontade sobre os outros e não a si mesmos.

O segundo campo no qual Constituições importam para a ciência política é o institucionalismo. Se, no primeiro, o debate envolve questões normativas, neste o interesse reside na explicação dos fenômenos políticos, com ênfase no papel das instituições. Tal como na disciplina de um modo geral, aqui também é possível falar em velho e novo institucionalismo dedicado às Constituições. Para o velho, Constituições funcionavam como repositórios de instituições, espécies de bancos de dados dos sistemas políticos que a disciplina se punha a pesquisar. Na perspectiva do velho institucionalismo, Constituições não são instituições elas mesmas, mas fontes de pesquisa para o estudo comparado das instituições políticas que elas encerram e como estas afetam o comportamento dos atores políticos e o processo decisório.

É no bojo do novo institucionalismo que Constituições passam a despertar o interesse da ciência política como instituições elas mesmas. Mais do que seu papel normativo no regime político ou para além das instituições que abrigam, as Constituições passam a importar como variável dependente dos processos de constitution-making e como variável independente de processos desencadeados por suas características intrínsecas. $O$ novo institucionalismo almeja a elaboração de teorias positivas, combinando na explicação os efeitos das instituições e a ação racional dos atores. Quando toma as Constituições como resultados, essa abordagem investiga os impactos que interesses, regras e expectativas futuras dos atores podem ter sobre as escolhas constitucionais no momento constituinte (ELKINS; GINSBURG; MELTON, 2009; ELSTER, 1995; GINSBURG; ELKINS; BLOUNT, 2009; KNIGHT, 2001), especialmente no que diz respeito ao maior ou menor grau de detalhamento do texto constitucional (DIXON, 2015; ELKINS; GINSBURG; MELTON, 2009), à organização de poderes voltada à eficiência geral ou à maximização de interesses partidários (NEGRETTO, 2013), à criação de tribunais constitucionais como salvaguardas diante da incerteza política futura (GINSBURG, 2003; GINSBURG; VERSTEEG, 2014; HIRSCHL, 2004; RIOS-FIGUEROA; POZAS-LOYO, 2010) e, mais recentemente, de que modo regimes democráticos têm reinstalado constituintes para substituir suas Constituições em pleno voo (NEGRETTO, 2020). 
No que diz respeito às Constituições como variável independente, as análises começaram há menos tempo e ainda não contam com número expressivo de trabalhos. Mas o início não podia ter sido mais ambicioso e promissor. Refiro-me ao censo constitucional realizado por Elkins, Ginsburg e Melton (2009). Adotando a perspectiva de Constituições como self-enforcing, os autores examinaram todas as que um dia existiram em países independentes entre 1789 e 2005, buscando explicação para o fato de que, embora tenham sido feitas para durar indefinidamente, a mediana de vida encontrada foi de apenas 19 anos. Examinando as causas da morte constitucional, os autores reconhecem que choques externos causam impacto sobre as Constituições e levam os atores a calcular os custos e benefícios de se viver sob determinada ordem constitucional ou de substituí-la por outra. Entretanto, são os fatores endógenos que melhor explicam as chances de sobrevivência das Constituições. Segundo os autores, os custos de uma substituição completa do texto constitucional são muito elevados, ao passo que o emendamento da Constituição pode funcionar para reformá-la ao mesmo tempo que a preserva. Assim, o estudo conclui que os atores políticos serão capazes de renegociar ponto a ponto os acordos constitucionais se as Constituições tiverem as seguintes características: 1) forem resultantes de processos de elaboração inclusivos e que reafirmam essa inclusividade no desenho das instituições políticas da nova ordem; 2) que contenham regras mais flexíveis do que rígidas de emendamento; e 3) que sejam mais detalhadas do que genéricas e que cubram o maior número de tópicos relevantes, funcionando como estacas que obrigarão a uma permanente renegociação constitucional, sempre que houver razões para mudá-las de posição. Inclusão, flexibilidade e especificidade - características endógenas à própria Constituição - reforçam-se mutuamente, criando um ciclo virtuoso em prol da sobrevivência constitucional. A propósito, a Constituição brasileira de 1988 figura no livro como um bom exemplo de Constituição, que reúne essas três características e, assim, dispõe de um grande potencial de endurance.

Numa perspectiva mais parcimoniosa, porém ainda institucionalista, se assumirmos como Hardin (2003) que uma Constituição não é um contrato - pois não dispõe de um garantidor externo - mas, sim, um mecanismo de coordenação entre atores relevantes, que instituições endógenas ao texto constitucional podem ser úteis à manutenção do equilíbrio self-enforcing da Constituição? São duas: a regra de emendamento e a existência de algum mecanismo ou sistema de controle de constitucionalidade das leis. Pelas oportunidades que propiciam e pelos limites que impõem à atuação legiferante da classe política, esses dois instrumentos asseguram simultaneamente a superioridade do texto constitucional diante de outros tipos de legislação e a possibilidade de atualizá-lo por mudança formal ou por interpretação 
judicial. Lijphart (1999), em seu estudo comparado de 36 democracias, demonstrou (embora de forma um tanto impressionista) que a rigidez constitucional estabelecida pela regra de emendamento e o controle constitucional pelo judiciário ou por uma corte constitucional caminham juntos nas democracias consensuais.

Mais de 90\% das Constituições existentes desde 1789 contiveram alguma regra de emendamento (ELKINS; GINSBURG; MELTON, 2009). Todavia, a diversidade de fórmulas e de exigências para alterar Constituições é notável: países experimentam diferentes quóruns de votação pelo legislativo, exigindo a formação de diferentes supermaiorias; outros realizam mais de um turno de votação ou requerem aprovação por mais de uma legislatura (com uma eleição popular entre elas); a ratificação por outras instâncias e poderes como unidades subnacionais (nos regimes federativos), cortes constitucionais e até pelo poder executivo ocorre em muitos outros, sem falar nos tradicionais referendos e plebiscitos, que exigem a manifestação popular direta. Naturalmente, os primeiros trabalhos sobre emendamento constitucional elaboraram hipóteses centradas nessas regras e aproveitaram essa diversidade para realizar análises comparativas. Lutz (1994, 1995) foi o primeiro autor a fazê-lo de modo abrangente e com resultados significativos, mas seus achados não se mostraram consistentes no longo prazo. Examinando o conjunto das Constituições estaduais americanas e uma seleção de países, Lutz lançou algumas proposições centrais, sendo duas as mais relevantes empiricamente: 1) quanto mais longa a Constituição, maior a probabilidade de uma elevada taxa de emendamento; 2) quanto mais difícil o processo de emendamento constitucional, menor a probabilidade de sua ocorrência. O problema do estudo pioneiro desse autor é que ele derivou o grau de dificuldade da regra de emendamento das taxas encontradas nos estados americanos, atribuindo a partir dessas taxas pesos às regras que presidiram sua ocorrência nas diferentes experiências estaduais. Trata-se da célebre afirmação do consequente, jamais notada por seus leitores. Talvez por essa razão, quando seu estudo foi replicado por outros autores com outras amostras, aqueles resultados não se confirmaram (LORENZ, 2005).

Diversos pesquisadores propuseram métodos alternativos de aferição da rigidez constitucional ou do grau de dificuldade do emendamento em perspectiva comparada (ANCKAR; KARVONEN, 2002; DIXON; HOLDEN, 2012; LIJPHART, 1999; LORENZ, 2005; NEGRETTO, 2012, 2013; NOLTE, 2008), mas, com exceção de alguns poucos achados consistentes, o debate permanece inconclusivo e nenhuma teoria foi capaz de se generalizar. Ginsburg e Melton (2015) chegaram a comparar esses diferentes métodos e demonstraram a baixa correlação entre eles, concluindo pela existência de um grave problema de validade dos resultados. Mais do que isso, vaticinaram que os testes de hipóteses que vinculam taxas de emendamento às regras 
institucionais que as presidem talvez jamais alcancem êxito. No lugar do estudo e da comparação dessas regras, os autores procederam a uma nova análise empírica pela qual concluíram que o melhor preditor da taxa de emendamento constitucional de um país é a taxa de emendamento da Constituição anterior desse mesmo país. A essa explicação deram o nome de "cultura do emendamento" que alguns países teriam, outros não. Tsebelis (2017) insurgiu-se contra essa explicação e recolocou a relevância das variáveis institucionais, demonstrando particularmente que Constituições longas mudam mais com o tempo, mesmo que sejam trancadas por regras rígidas de emendamento (e mais: segundo o autor, Constituições longas estão associadas a baixa renda per capita e elevados níveis de corrupção).

De fato, antes de nos resignarmos com a explicação culturalista, há dois elementos que merecem ser explorados. O primeiro diz respeito ao fato de que a maioria dos estudos se concentrou no grau de dificuldade imposto pela regra de emendamento, mas não se perguntou sobre os motivos que levam os atores a quererem mudar a Constituição. Se a premissa de que o custo de coordenação para substituir uma Carta inteira é maior do que o custo de reformá-la pontualmente está bem assentada na literatura inspirada na escolha racional, isto não exime essa mesma literatura de explicar por que atores relevantes arcariam com o custo do emendamento, que por sua vez é maior do que o de mudar o status quo por legislação ordinária. Ou seja, não é a regra que explica a taxa de emendamento, mas antes a razão de se empenhar e a articulação política necessária para fazer face a essa mesma regra. Falta, portanto, uma teoria da demanda no campo de estudos do emendamento constitucional. E antes que se recorra aos típicos fatores exógenos, cumpre se perguntar como o perfil endógeno da Constituição enceta a necessidade de seu próprio emendamento. É justamente esse ponto que investigamos no presente artigo e que nos levará ao conceito de Constituição policy-oriented.

O segundo elemento diz respeito ao controle constitucional pelo judiciário e/ ou pelas cortes constitucionais. Embora algumas análises reconheçam a importância da existência e força da judicial review na explicação da mudança constitucional, permanecem subteorizadas no campo as interações possíveis entre o perfil da Constituição, o emendamento e o controle constitucional. A existência de tribunais constitucionais fortes e ativos pode imprimir sobre o legislativo tanto uma postura deferente - e, nesse caso, teremos poucas iniciativas de leis inconstitucionais quanto pode levar o legislador a emendar frequentemente a Constituição como forma de se antecipar e/ou de se contrapor às cortes. No primeiro cenário, a Constituição permanecerá intacta graças à força de seu guardião. No segundo, ela será frequentemente reformada, independentemente ou mesmo graças à força dessa 
mesma vigilância judicial. Tais interações, evidentemente, são mediadas pelas regras institucionais que definem o grau de acesso aos tribunais e o efeito de suas decisões, bem como as que estabelecem o grau de dificuldade do emendamento constitucional. No exame do caso brasileiro feito nesse artigo, espera-se avançar na explicação de como o controle constitucional é afetado pelo perfil policy-oriented da Constituição e como suas decisões afetam a política constitucional voltada à constitucionalização de políticas públicas. Na próxima seção, trataremos do perfil da Constituição de 1988 e de seu emendamento frequente, oferecendo uma contribuição sobre a questão da demanda por mudança constitucional. Na seguinte, apresentaremos os dados relativos ao controle constitucional para, em seguida, mostrar como esses mecanismos interagem na política constitucional brasileira.

\section{A Constituição de 1988 e seu emendamento frequente: governando com uma Constituição policy-oriented}

Voltando ao estudo pioneiro de Lutz (1994, 1995), o autor chega a lançar a proposição de que, quanto mais funções governamentais uma Constituição contém, maior será a probabilidade de ser emendada. Todavia, na falta de teoria e método capazes de identificar essas funções e de comparar Constituições a partir delas, o autor abandona a ideia e decide subsumi-la na primeira proposição, a que trata do tamanho das Cartas. Diz ele que, quanto mais funções governamentais forem constitucionalizadas, maior será a Constituição, então tudo poderia ser resumido a uma questão de tamanho. Com essa decisão, perdeu-se a chance de distinguir qualitativamente o que Constituições de fato contêm e de que modo seu perfil endógeno pode causar impacto externo, afetando a política constitucional.

Elkins, Ginsburg e Melton (2009) deram um passo adiante quando, além de medir o tamanho das Cartas, elaboraram uma lista de 92 tópicos a partir da qual compararam o escopo das Constituições. Essa medida nos deu muito a conhecer sobre a forma como as Constituições evoluíram historicamente e sobre a importância, para a sua longevidade, da constitucionalização de inúmeros temas. Todavia, os autores não investiram na distinção qualitativa desses tópicos nem exploraram de que modo eles poderiam estimular, ou não, a renegociação constitucional frequente. Em poucas palavras, não completaram a tarefa de fazer da Constituição a variável independente dos processos de emendamento ou de controle constitucional que Cartas podem desencadear. 
Assim, a pergunta que cabe fazer é de que modo o perfil endógeno de uma Constituição pode impulsionar a política constitucional ao seu redor? Desde trabalhos anteriores (ARANTES; COUTO 2008, 2009, 2010, 2012, 2019; COUTO; ARANTES, 2003, 2006, 2008, 2020), temos demonstrado que Cartas constitucionais nem sempre se limitam a estabelecer a forma básica do Estado e os direitos fundamentais, mas podem se arvorar à constitucionalização de políticas públicas, causando, assim, impacto direto sobre a agenda governamental, que se desdobra em frequente processo de emendamento e estímulo adicional à judicialização dessas mesmas políticas públicas. Em outras palavras, é possível combinar a origem endógena da demanda por política constitucional permanente e os mecanismos institucionais disponíveis, na análise do emendamento pelo legislativo e do controle constitucional pelo judiciário. O argumento central desenvolvido nos referidos trabalhos é que a Constituição brasileira de 1988 é uma Constituição policy-oriented, a qual não apenas constitucionalizou políticas públicas na origem, mas ensinou os governantes futuros a governarem por meio dela.

A Metodologia de Análise Constitucional (MAC) propõe-se a distinguir, no interior dos textos constitucionais, dispositivos fundamentais (denominados polity) de dispositivos veiculadores de políticas públicas (denominados policy). A MAC é composta de três etapas: teórica, conceitual e empírica. Resumiremos a seguir essas etapas, mas o leitor interessado no seu detalhamento pode recorrer às referências supracitadas. Em termos teóricos, a distinção entre polity e policy é elaborada com o intuito de superar o argumento formalista de que tudo o que está numa Constituição deve ser considerado constitucional. Nessa perspectiva, polity diz respeito à estruturação da comunidade política, incluindo a organização básica do Estado e os elementos da nacionalidade, as regras que presidem as relações entre poderes, órgãos e instituições, bem como os direitos fundamentais de liberdade, de participação e de proteção material. Em poucas palavras, é o que comumente se espera de uma Constituição. Postula-se que tais elementos devem ser caracterizados por certa generalidade e relativa neutralidade, pois devem expressar um consenso político básico capaz de promover a adesão de todas as forças políticas e evitar a deserção do pacto constitucional. De outro lado, denominam-se policy as normas relativas a políticas públicas. Por contraste com a normatividade constitucional, estas não precisam ser neutras nem genéricas, pois expressam preferências transitórias, de recorte quase sempre partidário e sujeitas à alternância no poder. Em poucas palavras, é o que comumente se espera das medidas de nível governamental. 
Se das definições de polity se presume que serão duradouras, porque estruturais, das normas de policy se presume que poderão mudar de acordo com a conjuntura, que serão disputadas entre as forças políticas e serão suscetíveis à vontade das maiorias democraticamente eleitas. Direitos sociais podem muito bem compor a polity, mas as políticas voltadas à sua implementação devem ser desenhadas e implementadas no plano governamental. Não é necessário nos estendermos demasiadamente para concluir que, no mundo ideal, polity e policy deveriam constituir dimensões separadas e discerníveis do regime político. Dessa distinção dependeria a própria sorte da democracia constitucional. Enquanto a normatividade constitucional se ocupa do necessário para projetar e unir a comunidade política, conservando-a de modo duradouro, a normatividade governamental é o terreno no qual a democracia pode produzir seus efeitos, transformando o status quo a partir da vontade majoritária vitoriosa em eleições livres e competitivas.

Uma vez estabelecidas as distinções teóricas entre polity e policy, a segunda etapa da MAC é conceitual, no sentido de traduzir aquelas diferenças em elementos observáveis no interior dos textos constitucionais, daí a necessidade de reuni-los em conceitos. Com base na teoria política e na experiência histórica dos estados constitucionais, Couto e Arantes (2006) postulam que a polity democrática é formada por quatro elementos básicos, a saber: 1) definições de Estado e Nação (sua estrutura básica, seus contornos externos e internos, incluídas as subdivisões regionais, étnicas, culturais ou outras, seu território, o regime político adotado e os critérios de nacionalidade e que conformam o povo); 2) direitos individuais fundamentais, que estruturam a cidadania e os termos básicos de sua relação com o Estado. Estão inclusos nessa dimensão os direitos de liberdade e os direitos de participação política, por meio dos quais os indivíduos se protegem (liberdade negativa) e podem exercer influência nas ações do Estado e nos destinos da própria comunidade política (liberdade positiva). Em termos básicos, são os direitos civis e políticos; 3) regras do jogo, as quais constituem os procedimentos que organizam as interações no interior da polity: eleições e outras formas de preenchimento dos cargos públicos, relações entre órgãos, poderes e níveis de governo, normas de formação e funcionamento da burocracia e regras para os processos decisórios (administrativos, legislativos e judiciais); e 4) direitos materiais e de acesso ao bemestar constituem a polity na medida em que promovem a adesão de todos ao pacto democrático (COUTO, 2005). A expressão direitos materiais é preferível a direitos sociais porque nela estão incluídos também direitos de cunho mais individual - como os direitos à propriedade e à segurança - além dos reconhecidamente sociais - como os direitos a educação, saúde, trabalho etc. Embora essa quarta dimensão da polity se 
aproxime da policy, não se deve confundir tais direitos - definidos como princípios fundamentais - com as políticas públicas desenhadas para a sua implementação. Enquanto os direitos constitucionais tendem a ser fixos e permanentes, as políticas podem variar a critério das maiorias democraticamente eleitas.

Por policy, a metodologia compreende aqueles dispositivos voltados a estabelecer como o Estado deve agir de modo a atingir determinadas finalidades. Muitas vezes esse como envolve a previsão de ações específicas, estabelece parâmetros obrigatórios, ostenta metas, escolhe instrumentos e pré-define grupos a serem beneficiados. Consequentemente, quando tais aspectos são constitucionalizados, a condução das políticas públicas deixa de ser prerrogativa de governos majoritários comuns e passa a depender de supermaiorias legislativas necessárias ao emendamento constitucional. Além de policy encontrada em estado puro na Constituição, essa abordagem identificou dispositivos que, embora associados aos quatro tipos de polity, ganham redação tão específica e controversa que contradiz os princípios da generalidade e da neutralidade que devem caracterizar dispositivos propriamente constitucionais, tal como postulado pela metodologia.

A terceira etapa da MAC é propriamente empírica. Planilham-se os textos constitucionais na forma de dispositivos, e estes são classificados como polity (na forma dos quatro subtipos descritos acima, podendo haver dispositivos com mais de um sentido) ou como policy (especificando se se trata de policy pura ou por especificidade e controvérsia). Define-se dispositivo como a menor unidade de texto constitucional dotada de sentido completo. Para delimitá-lo, não se deixa de aproveitar a estrutura formal composta por artigos, parágrafos, incisos e alíneas que formam a Constituição, mas estes são decompostos ou agrupados até que formem as tais menores unidades dotadas de sentido completo. ${ }^{4}$

Assim, resumidamente, é com base nessas três etapas que se logra distinguir substantivamente dispositivos constitucionais estruturais (polity) de dispositivos veiculadores de políticas públicas (policy), algo que as análises meramente formais não conseguem realizar. A importância de produzir essa distinção reside na possibilidade de contribuir para explicar a demanda por mudança constitucional, a intensidade e a extensão pelas quais se empenham os agentes da política constitucional, seja por via do emendamento, seja pela via do controle constitucional. Constituições que contém

\footnotetext{
${ }^{4} \mathrm{Na}$ literatura estrangeira que se arriscou a medir Constituições, autores como Anckar e Karvonen (2002) contaram diretamente os artigos constitucionais. Lutz (1994), Elkins, Ginsburg e Melton (2009), Tsebelis e Nardi (2016), entre outros, contaram palavras. Lorenz (2005) usou artigos e linhas em sua análise. Tais estratégias, embora mais simples, não nos permitiriam formar unidades de texto exclusivas e dotadas de sentido completo passível de classificação.
} 
apenas dispositivos de polity têm impacto bastante diferente daquele de constituições que carregam políticas públicas. A constitucionalização de policy atrai para o marco constitucional os agentes interessados na mudança do status quo da política, impulsionando a política constitucional para além do que a literatura convencional está habituada a pensar (porque tem como modelo de constituição apenas aquela assentada em elementos de polity). Em suma, regras de emendamento bem como as de acesso ao controle constitucional e seu escopo certamente influenciam a dinâmica da política constitucional, mas é preciso saber o que leva os atores a acionarem esses instrumentos. Políticas públicas constitucionalizadas nos parecem um forte motivo para isso.

Aplicada à Constituição de 1988, a Metodologia de Análise Constitucional de Couto e Arantes (2006) identificou 1.627 dispositivos contidos nos 245 artigos de seu texto principal (enquanto o Ato das Disposições Constitucionais Transitórias resultou em 228 dispositivos). Examinadas igualmente todas as emendas constitucionais aprovadas entre 1992 e 2020 (incluindo 108 emendas regulares e 6 aprovadas pela Revisão Constitucional de 1994), tem-se nada menos do que 1.737 dispositivos de emendas (COUTO; ARANTES, 2020). Classificados os 1.627 dispositivos da Constituição original (exceto $\mathrm{ADCT}^{5}$ ), identificaram-se 69,3\% de polity e 30,7\% de policy no interior do texto constitucional. Não cabe, nos limites deste artigo, reapresentar todos os resultados das aplicações dessa metodologia alcançados até agora (esses podem ser encontrados em outros trabalhos ${ }^{6}$ ), mas é possível afirmar que a taxa de constitucionalização de políticas públicas da Constituição de 1988 supera significativamente as taxas encontradas nas Constituições brasileiras anteriores e nas Constituições estrangeiras comparadas.

De fato, como previsto inicialmente, esse perfil policy-oriented da Carta de 1988 ensejou, também graças a uma regra de emendamento não tão rigorosa, seu permanente emendamento posterior. Diferentemente de autores que tomaram o emendamento como resultado apenas da combinação de regras e contexto (especialmente da reforma do Estado nos anos 1990), e chegaram até mesmo a prever o arrefecimento do fenômeno (MELO, 2007, 2013; SOUZA, 2008, 2013), a Constituição de 1988 seguiu sendo reformada ao longo dos sucessivos governos, ainda que com diferentes agendas e distintas inclinações ideológicas, numa das taxas de emendamento mais

\footnotetext{
${ }^{5}$ Por sua natureza especial de regra de transição, preferimos inicialmente não classificar o ADCT em termos de polity e policy (COUTO; ARANTES, 2006).

${ }^{6} \mathrm{~A}$ análise dos resultados relativos à Constituição de 1988 pode ser encontrada em Couto e Arantes (2006 e 2008), sobre Constituições brasileiras anteriores a 1988 em Arantes e Couto (2008), sobre o emendamento constitucional pós-88 em Arantes e Couto $(2009,2012,2019)$ e em Couto e Arantes (2020), sobre outras Constituições em perspectiva comparada em Arantes e Couto $(2019,2020)$.
} 
elevadas do mundo. E, confirmando nossa primeira hipótese de modo estatisticamente significante, os dispositivos originais de policy foram reformados a uma taxa duas vezes maior que os dispositivos de polity.

Nossa Constituição policy-oriented revelaria uma surpresa maior do que a tentativa de cristalizar políticas e de obrigar as gerações futuras a renegociarem-nas de modo permanente no modus operandi constitucional. Mais do que o conteúdo, a Carta de 1988 legou um padrão de governar por meio da Constituição, de tal modo que os sucessivos governos recorreram ao emendamento não apenas para corrigir dispositivos da Carta original, mas para constitucionalizar novas políticas em proporção ainda maior. O gráfico 1 apresenta, na forma de dispositivos, o conjunto das emendas constitucionais aprovadas entre 1992 e 2020.

Gráfico 1. Disposivitos de Emendas Constitucionais aprovados por ano e impacto sobre o texto original (1992-2020)

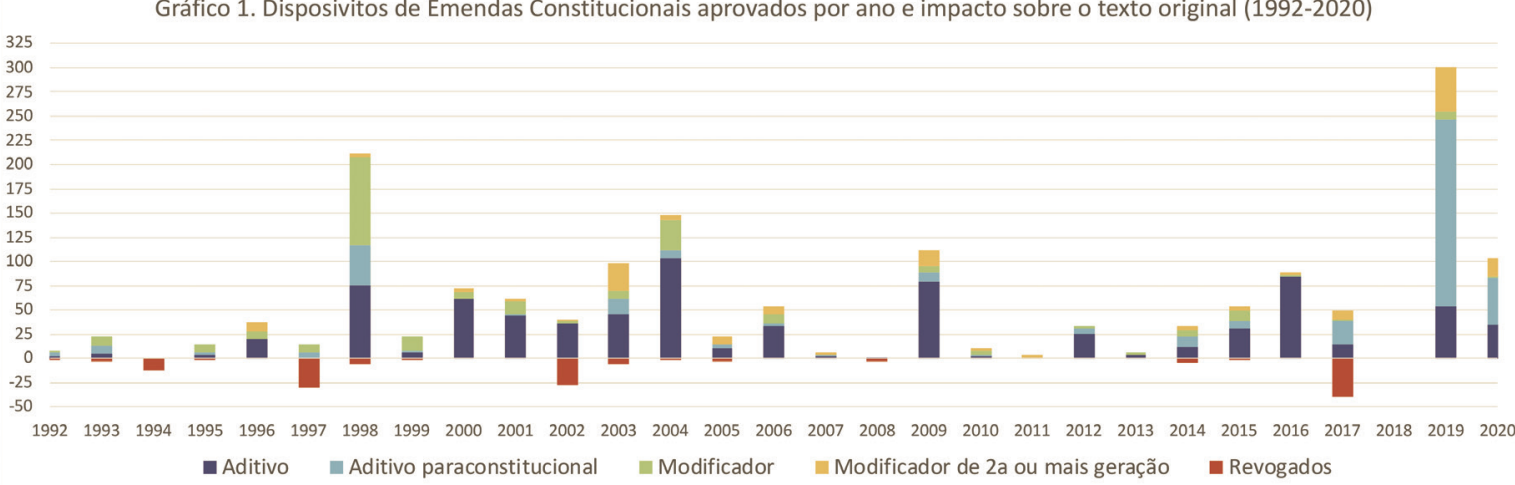

Fonte: Elaborado pelo autor.

Nesse período, foram 108 emendas regulares e 6 emendas aprovadas pela Revisão Constitucional de 1994. Quando examinadas as emendas na forma de dispositivos no Gráfico 1, impressiona o fato de que, ao contrário do que afirma o senso comum, as emendas tenham acrescentado nada menos do que 1.189 novos dispositivos e suprimido apenas 143, o que nos permite dizer que a Constituição brasileira cresceu 56,4\% em pouco mais de trinta anos. Esse crescimento tem se dado até mesmo na forma paraconstitucional, que são dispositivos que habitam o texto das emendas, mas não são colados ao texto principal. Para todos os efeitos,

\footnotetext{
${ }^{7}$ Considerando 114 emendas aprovadas até 2020 (108 regulares e 6 de Revisão), 285 dispositivos da Constituição original foram atingidos por emendamento pelo menos uma vez (em alguns casos, o mesmo dispositivo foi reformado mais de uma vez). Entre os dispositivos de polity, foram 150 ou 13,3\% do total de polity. Entre os dispositivos de policy, foram 135 ou $27,1 \%$ do total de policy, ou seja, o dobro da taxa de polity. O teste chi-quadrado e os resíduos ajustados mostram que a policy é mais reformada do que a polity, com resultado estatisticamente significante.
} 
são constitucionais como quaisquer outros e somente poderão ser reformados por novas emendas constitucionais. Exemplo eloquente disso foi a extensa reforma da Previdência de 2019, com 185 aditivos paraconstitucionais em meio a um total de 266 dispositivos. As gerações futuras que quiserem reformar a Previdência terão de reunir 3/5 dos deputados e senadores para enfrentá-los, dentro do texto principal e no mundo paralelo das emendas. No geral, os aditivos paraconstitucionais foram responsáveis por 33\% da taxa de crescimento global da Constituição e hoje representam 13,8\% do marco constitucional brasileiro.

Examinando os 860 dispositivos acrescentados à Carta entre 1992 e 2017, verifica-se que foram veiculados 79,4\% novos dispositivos de policy e 20,6\% de polity, invertendo e mais do que dobrando a taxa de constitucionalização de políticas públicas do texto original. Conquanto a estratégia de constitucionalizar políticas possa variar de acordo com as fontes de resiliência do tipo de policy, conforme demonstraram Couto e Lima (2016), cabe perguntar o que levou as sucessivas maiorias políticas a lotar ainda mais a Constituição de políticas públicas? Na literatura sobre o presidencialismo de coalizão, ênfase é dada à força do Executivo na aprovação da agenda legislativa de seu interesse (FIGUEIREDO; LIMONGI, 1999), mas os estudos nesse campo se concentraram na produção de legislação ordinária e pouca atenção foi dada às especificidades do emendamento constitucional. Quando o federalismo é o objeto de interesse, as emendas constitucionais se destacam, como nas análises de Arretche $(2012$, 2013), que demonstraram a força da União em impor suas políticas aos estados, via emendamento. Em trabalho recente, Couto e Arantes (2020) avançam um tanto mais para demonstrar que a constitucionalização de políticas não pode ser atribuída apenas aos interesses do Executivo em congelar suas preferências, mas a uma dinâmica mais complexa da política constitucional na qual se sobressai o Poder Legislativo. Com base em novas evidências, os autores argumentam que o emendamento permanente no Brasil reflete a estratégia da maioria legislativa de superar ou dificultar a ação dos veto players em relação às suas preferências por políticas, notadamente os estados da Federação, o Judiciário e muitas vezes o próprio Executivo (COUTO; ARANTES, 2020).

Em resumo, a política constitucional por via do emendamento no Brasil deita raízes na constitucionalização de policy levada a cabo em 1988, mas não se limita à revisão daquele marco inicial, tendo prosseguido por trinta anos como uma forma pela qual maiorias legislativas governam a Federação e os demais poderes. 


\section{O STF e o controle constitucional de políticas públicas}

A forma como regimes políticos lidam com suas Constituições vai além das regras de emendamento. Mesmo essa, especificamente, depende, como vimos na seção anterior, de motivos para serem desafiadas pelos agentes políticos. Dependendo da forma como se combinam e das demais características do sistema político, uma Constituição poderá tanto permanecer praticamente intacta - como a dos Estados Unidos - como se transformar em uma quase lei ordinária geral das políticas públicas constitucionalizadas, como a brasileira. O segundo mecanismo institucional que determina a sorte das Constituições é, como adiantamos na seção II, o controle constitucional. É dele que essa seção trata.

Evidentemente, a primeira hipótese que se deve investigar é a de que o judicial review, idealizado historicamente para proteger as regras da polity, tem funcionado no Brasil também no plano das políticas públicas, por conta da elevação dessas ao marco constitucional. Em outras palavras, é de se esperar que o Judiciário brasileiro e especialmente o STF sejam chamados a interferir na produção e implementação das políticas de governo, uma vez que elas estão constitucionalizadas e, por esse meio, sua judicialização pode ser exponencializada. Veremos a seguir como isso de fato acontece, mas tal hipótese não descreve por completo o que se passa no âmbito da revisão judicial e o seu papel na política constitucional brasileira.

A interferência do Judiciário em políticas públicas no Brasil é tema de grande interesse e já conta com significativa produção acadêmica ${ }^{8}$. Todavia, ainda são poucos os trabalhos que, para além dos estudos de caso, examinaram essa temática de forma mais abrangente no STF (MADEIRA, 2014; OLIVEIRA, 2019). Essa seção apresenta os resultados da aplicação da Metodologia de Análise Constitucional no exame das ações diretas de inconstitucionalidade ajuizadas no STF entre 1988 e 2015, a fim de verificar em que medida a combinação de uma Constituição policy-oriented e um sistema de controle direto da constitucionalidade das leis de amplo acesso a atores sociais e políticos faz do caso brasileiro um exemplo não só de Constituição muito emendada como de intensa interferência do Judiciário em políticas públicas.

A decisão de transferir autoridade de policy-making a tribunais constitucionais está relacionada à configuração de forças políticas no momento constituinte e às expectativas dos diversos partidos em relação ao futuro. Segundo Ginsburg (2003),

\footnotetext{
${ }^{8}$ Uma boa amostra dessa produção encontra-se na coletânea organizada por Oliveira (2019), que conta com uma apresentação sintetizando as principais questões de interesse desse campo de estudos.
} 
processos de elaboração constitucional caracterizados por fragmentação política elevam a incerteza dos atores sobre o futuro, fazendo com que adotem um sistema de controle constitucional forte e acessível, como forma de insurance, para a proteção de seus interesses no longo prazo. Transferir poder a juízes e tribunais representa um custo para as elites políticas, mas elas adotarão essa solução se os custos estimados de perdas eleitorais futuras lhes parecerem maiores do que os custos dessa delegação. Radicalizando o argumento, Hirschl (2004) afirma que a constitucionalização de direitos e interesses, associada à criação de tribunais constitucionais em diversos países, tem configurado o fenômeno da juristocracy, uma espécie de domínio orquestrado por elites políticas, econômicas e judiciais empenhadas em assegurar sua hegemonia, preservar direitos de propriedade e aumentar seu poder de influência na esfera nacional e até internacional. Jack Knight (2001), de maneira mais parcimoniosa, formulou um modelo teórico bastante persuasivo, mostrando como as expectativas políticas em relação ao futuro são capazes de induzir no presente as escolhas dos constitution-makers, em três dimensões principais: 1) o grau de detalhamento do texto constitucional; 2) a maior ou menor dificuldade de emendamento constitucional; e 3) o escopo e o grau de acesso da revisão judicial das leis. Segundo Knight (2001), as escolhas nessas três dimensões dependerão da expectativa das forças políticas em relação a quais preferências serão majoritárias no Legislativo e no Judiciário no futuro. No caso de a força política, ou mesmo a coalizão que escreve a Constituição, considerar que suas preferências não serão majoritárias no futuro em nenhum dos poderes, ou se houver elevada incerteza a este respeito, as decisões serão 1) por uma Constituição formada de provisões detalhadas e específicas (amarrando o futuro às preferências do presente); 2) por um sistema de controle constitucional de amplo escopo e amplo acesso (porque, na hipótese de não controlar o Legislativo, será possível recorrer ao judicial review contra as decisões do legislador majoritário); e também 3) por uma regra de emendamento fácil (porque, na hipótese de desacordo com as decisões judiciais, será possível mudar a própria Constituição).

Tudo indica que a constituinte de 1987-1988 tomou, em conjunto, as três decisões mencionadas acima. Melo (2013), inspirado no modelo de Knight, revisitou o debate constituinte e mostrou como os parlamentares adotaram conscientemente duas soluções aparentemente contraditórias: uma Constituição extensa e detalhada e, ao mesmo tempo, mais fácil de mudar (com exceção do núcleo duro representado pelas cláusulas pétreas). Quanto ao controle constitucional, pode-se acrescentar que os constituintes brasileiros adotaram de fato um sistema de amplo escopo e francamente acessível (ARANTES 1997, 2005, 2013, 2015), mas o caminho até esse resultado 
foi sinuoso. Segundo Koerner e Freitas (2013), os progressistas queriam a criação de um tribunal constitucional ao estilo europeu, pois não confiavam em delegar à magistratura comum o futuro da interpretação da nova Constituição. Todavia, os conservadores, com o apoio do próprio STF, lograram êxito em manter o sistema híbrido herdado do período anterior, no qual a competência de revisão judicial das leis está distribuída por toda a magistratura - que pode exercê-la de forma incidental no julgamento de casos concretos - mas também pode ser exercida pelo STF na forma direta e abstrata, para além dos recursos extraordinários oriundos da parte difusa do sistema, isto é, das instâncias inferiores. Assim, o STF manteve e viu reforçada suas múltiplas funções de tribunal constitucional (na forma direta e recursal, abstrata e concreta), além de órgão de cúpula do Judiciário nacional, tribunal da Federação e foro especial para julgamento de altas autoridades, entre outras (ARANTES, 1997, 2005, 2013). Ainda em consonância com o modelo de Knight (2001), os progressistas perderam na tentativa de criar uma corte constitucional exclusiva, mas conseguiram aprovar a ampliação do acesso ao STF de modo bastante significativo, aumentando de um para nove os tipos de agentes legitimados a provocar o Tribunal no controle dos atos normativos dos demais poderes. Antes restrita ao Procurador-Geral da República, a lista de legitimados tornou-se uma das mais generosas do mundo, ultrapassando até mesmo os países que adotam cortes constitucionais de modelo concentrado, conforme estabelece o já bastante conhecido art. 103 da Constituição de 1988.

Nos anos seguintes, o sistema de controle constitucional passaria por ajustes importantes, que, de modo geral, ampliaram ainda mais o escopo de atuação e a força das decisões do STF. Em especial, a Emenda Constitucional 45/2004 instituiu a Súmula de Efeito Vinculante e a Repercussão Geral, concentrando mais a competência de controle constitucional no Tribunal e permitindo-lhe administrar com maior discricionariedade o volume de causas que lhe chegam pela via recursal. Outras mudanças legais desdobraram o subsistema de controle direto de constitucionalidade em quatro tipos de ação, intensificando ainda mais a dinâmica da política constitucional a partir do acionamento do STF. São elas a ação direta de inconstitucionalidade (ADI), ação direta de inconstitucionalidade por omissão (ADO), ação declaratória de constitucionalidade (ADC) e arguição de descumprimento de preceito fundamental (ADPF). Por meio dessas ações e da modulação de decisões, o STF pode ir além da função contramajoritária clássica, de legislador negativo, para declarar omissão legislativa, preencher lacunas, oferecer interpretação da lei conforme a Constituição (fixando essa interpretação), determinar no tempo quando suas decisões devem produzir efeito, além de alcançar atos normativos de todos os níveis e ramos de 
poder, atuais ou passados, corrigindo aqueles que ferirem preceitos fundamentais. Em perspectiva comparada, trata-se, sem dúvida, de um Tribunal superlativo.

Apresentamos a seguir os resultados da investigação sobre as ações diretas de inconstitucionalidade, realizada com base nas técnicas da Metodologia de Análise Constitucional e juntando informações adicionais a partir de bancos de dados de acesso público (CANELLO, 2016b; MARIANO SILVA, 2018a). Em março de 2021, o site do STF informava o acumulado de 6.700 ADIs. A judicialização da política constitucional alcançou essa incrível cifra graças a um conjunto de fatores. A ADI pode ser usada contra normas federais e estaduais, e a lista de agentes legitimados é composta por atores oriundos dos dois níveis da Federação e de diversos ramos de poder, propiciando assim um controle cruzado multidimensional. Além da legitimação intra e inter jurisdições da Federação, a lista inclui atores sociais e corporativos, partidos políticos e o Procurador-Geral da República, que expandem sobremaneira o potencial de ativação da política constitucional no País.

Extensa literatura de ciência política e direito foi produzida sobre o Supremo Tribunal Federal nos últimos anos, examinando diferentes aspectos do lugar institucional e do funcionamento do Tribunal (ARANTES; ARGUELHES, 2019). Especificamente sobre o controle concentrado e direto de constitucionalidade, podese dizer que os primeiros estudos se centraram no desenho institucional do sistema, em análises descritivas e estudos de casos de ações (ARANTES, 1997; TAYLOR, 2008; VIANNA; CARVALHO; MELO; BURGOS, 1999; VIANNA; BURGOS; SALLES, 2007; VIEIRA, 1994). A estes se seguiram trabalhos que procuraram qualificar a real extensão da judicialização da política constitucional e a questionar a atuação do STF como verdadeiro ator de veto (NUNES, 2010; OLIVEIRA, 2005; POGREBINSCHI, 2011), a examinar seu desempenho a partir de dimensões específicas como a da Federação (CANELLO, 2016a; OLIVEIRA, 2009) ou da provocação por partidos políticos (BOGÉA, 2018; TAYLOR; DA ROS, 2008), concentrando-se recentemente no comportamento decisório dos ministros, na busca da racionalidade do voto e na formação de grupos e coalizões (ARAÚJO, 2017; DESPOSATO; INGRAM; LANNES, 2014; FERREIRA; MUELLER, 2014; MARTINS, 2018; OLIVEIRA, 2011, 2012 e 2017; MARIANO SILVA, 2018b). De modo incipiente, mas promissor, trabalhos que buscam integrar numa sintonia mais fina a atividade de judicial review e a produção legislativa nos marcos do presidencialismo de coalizão também começam a se destacar (OLIVEIRA, 2018; OLIVEIRA; ARGUELHES, 2021). A esta agenda vimos acrescentar a presente análise sobre o impacto do perfil da Constituição sobre a agenda de judicial review pelo STF, com ênfase na dimensão do acionamento do Tribunal. 
Entre outubro de 1988 e o final de 2015, deram entrada no STF 5.353 ADIs. ${ }^{9}$ Trata-se de um largo período, ao longo do qual tanto o STF quanto o País experimentaram diferentes contextos, marcados por diferentes agendas. No caso do Tribunal, houve expressiva mudança de composição interna, e, comparativamente ao estabelecido em 1988, suas competências relativas ao controle constitucional foram mais bem definidas (entre outras, pelas Leis 9.868/1999 e 9.882/1999) e reforçadas (pelas Emendas 3/1993 e 45/2004), redesenhando suas relações com os demais poderes e com as instâncias inferiores do Judiciário, configurando o que Vieira chamou de supremocracia (VIEIRA, 2008). O contexto político e a saliência das políticas, tão importantes para compreender os padrões de acionamento da Corte (TAYLOR, 2008), também passaram por importantes mudanças. Assim, os primeiros anos de nossa série temporal de ADIs se caracterizam pela implantação do novo texto constitucional e pelas novidades em relação ao próprio sistema de controle, com destaque para a ampliação do número de agentes legitimados a acionálo. Nesse período, o STF passou por dois testes de força importantes, derivados da agenda política do País: a elaboração das novas Constituições estaduais, que foram amplamente questionadas no Supremo por parte tanto de governadores eleitos em 1990 como do Procurador-Geral da República (VIANNA; CARVALHO; MELO; BURGOS, 1999), e as reformas econômicas e do Estado que suscitaram, num primeiro momento, ações dos partidos de oposição contra o governo Collor e, num segundo, de partidos de oposição contra o governo FHC. Quando chegamos na outra ponta da série histórica de ADIs em 2015, já estamos diante de um novo STF e de um novo País. O Tribunal teve sua composição bastante alterada pelas nomeações dos governos petistas a partir de 2003, e seus poderes institucionais foram reforçados pela reforma do Judiciário, como já mencionado. Segundo Desposato, Ingram e Lannes (2014), ministros ou grupos de ministros passaram a adotar comportamento ideológico mais assertivo, reforçando divisões oriundas das diferentes indicações presidenciais, justamente quando o Tribunal teve sua autoridade institucional fortalecida pela reforma constitucional do Judiciário. Aquela Corte, que no início havia se mostrado mais deferente aos demais poderes, havia assumido lugar central na cena política e social brasileira, viu sua agenda ser ampliada e renovada (com a introdução de outros temas de políticas públicas, mas também relativos à competição política, às relações entre os poderes e ao combate à corrupção) e passou a guardião de uma Constituição cada vez maior, resultante do emendamento constitucional permanente. E da ideia de

\footnotetext{
${ }^{9} \mathrm{O}$ observador leigo que considerar apenas a numeração dirá que foram 5.445, que correspondem ao número de identificação da última ADI que deu entrada no STF no ano de 2015. Entretanto, por razões ainda desconhecidas, há 92 números fantasmas no intervalo entre a ADI 1 e a ADI 5.445, isto é, não há de fato ações associadas a esses números. Por isso, o saldo geral é de 5.353 ADIs.
} 
supremocracia passamos à de ministrocracia (ARGUELHES; RIBEIRO, 2018b), desde que a dimensão da atuação individual dos ministros ganhou maior relevo no estudo do comportamento decisório e dos poderes individuais dos integrantes da Corte (ARGUELHES; HARTMAN, 2017; ARGUELHES; RIBEIRO 2015, 2018a).

Quando os diferentes atores legitimados ingressam com ADI no STF, eles devem fundamentar seu pedido com base em dispositivos da Constituição. O presente artigo examinou as 5.353 ADIs movidas entre 1988 e 2015 em busca dessa fundamentação. Em meio a esse grande universo, 498 ADIs não dispunham dessa informação ${ }^{10}$, ao passo que outras 7 continham erros que inviabilizaram seu aproveitamento na análise. Somadas, 505 ADIs foram descartadas, e, desse modo, a análise se concentrou em 4.848 ações. O passo seguinte foi associar manualmente os dispositivos citados na fundamentação à codificação de dispositivos na base MAC.

Considerando os 1.627 dispositivos originais da Constituição de 1988, a análise das ADIs revelou que 1.138 já foram invocados individualmente em ações diretas, ou seja, 70\% do texto constitucional já foi acionado como fundamentação na tentativa de derrubar leis e atos normativos. Dentre os dispositivos citados, $70 \%$ são polity e 30\% são policy, miraculosamente a mesma proporção que encontramos na Constituição original. Em outras palavras, o acionamento do controle constitucional espelha matematicamente o perfil do texto constitucional original, confirmando nossa hipótese principal. Por outro lado, como se pode observar pela tabela 1, embora o número de dispositivos originais modificados por emenda seja bem menor (273), a maioria deles $(78,8 \%)$ já foi citada como fundamentação em ADI. Esses 215 dispositivos (citados e emendados) compõem o centro das controvérsias da política constitucional brasileira. No entanto, vale também concluir que os mundos do controle constitucional (no qual 1.138 dispositivos originais são invocados) e o do emendamento constitucional (no qual 273 dispositivos originais foram reformados) são relativamente independentes e provavelmente complementares, como veremos adiante.

\footnotetext{
${ }^{10}$ Destas, 477 eram ADIs convencionais e 21 eram ADIs por omissão, quando estas não eram ainda catalogadas à parte pelo Tribunal. Em geral, a falta de informação sobre a fundamentação está associada a ações indeferidas preliminarmente pelo Tribunal, muitas por ilegitimidade do autor, perda do objeto ou julgadas prejudicadas por outros motivos. Desse modo, a exclusão dessas ações não acarretou perdas substantivas do ponto de vista que interessa ao presente artigo.
} 


\section{Tabela 1 - Dispositivos da CF 1988 citados em ADI e modificados por emendas constitucionais}

\begin{tabular}{|c|c|c|c|c|}
\hline & & \multicolumn{2}{|c|}{ Emendados } & \multirow{2}{*}{ Total } \\
\hline & & não & $\operatorname{sim}$ & \\
\hline \multirow{2}{*}{ Citados em ADI } & não & $\begin{array}{c}431 \\
(26,5 \%)\end{array}$ & $\begin{array}{c}58 \\
(3,6 \%)\end{array}$ & $\begin{array}{c}489 \\
(30,1 \%)\end{array}$ \\
\hline & $\operatorname{sim}$ & $\begin{array}{c}923 \\
(56,7 \%)\end{array}$ & $\begin{array}{c}215 \\
(13,2 \%)\end{array}$ & $\begin{array}{c}1.138 \\
(69,9 \%)\end{array}$ \\
\hline \multicolumn{2}{|c|}{ Total } & $\begin{array}{c}1.354 \\
(83,2 \%)\end{array}$ & $\begin{array}{c}273 \\
(16,8 \%)\end{array}$ & $\begin{array}{c}1.627 \\
(100 \%)\end{array}$ \\
\hline
\end{tabular}

Fonte: Elaborado pelo autor.

Dado que uma mesma ADI pode acionar mais de um dispositivo na fundamentação constitucional, as 4.848 ações contabilizaram um total de 18.865 citações de dispositivos. Embora a média de citações seja de 4 dispositivos por ação, esse valor é puxado para cima por algumas ações extravagantes que chegaram a invocar mais de 20 dispositivos, como se pode ver pelo gráfico 2 , que traz também os dispositivos que, acrescidos por emendas, foram citados na fundamentação de ADIs. ${ }^{11}$

\footnotetext{
${ }^{11}$ Uma das ações, a ADI 1.923, citou 66 dispositivos e, por essa razão, foi (a única) retirada do gráfico 2, pois comprometia excessivamente a visualização das demais. Observando com maior cuidado, uma maioria de 23\% de ADIs citou apenas um dispositivo, $19 \%$ citaram dois, e 17\% citaram três, totalizando 59\% de ações com até 3 dispositivos. Apenas 10\% das ações citaram acima de 8. Dispositivos do ADCT foram citados em 353 ADIs, mas optamos por não representá-los no gráfico 2. Quando a fundamentação citou artigos que compreendiam mais de um dispositivo, sem especificá-los, examinamos esses subconjuntos de modo a verificar a quantidade de polity e de policy contida por eles e os classificamos como unidades, conforme a direção da maioria dos dispositivos contidos no intervalo (nos casos de empate, o voto de minerva foi concedido a polity). Foram 276 intervalos classificados como policy e 1251 como polity.
} 
Gráfico 2. Dispositivos Polity e Policy citados em ADI

(1988-2015)

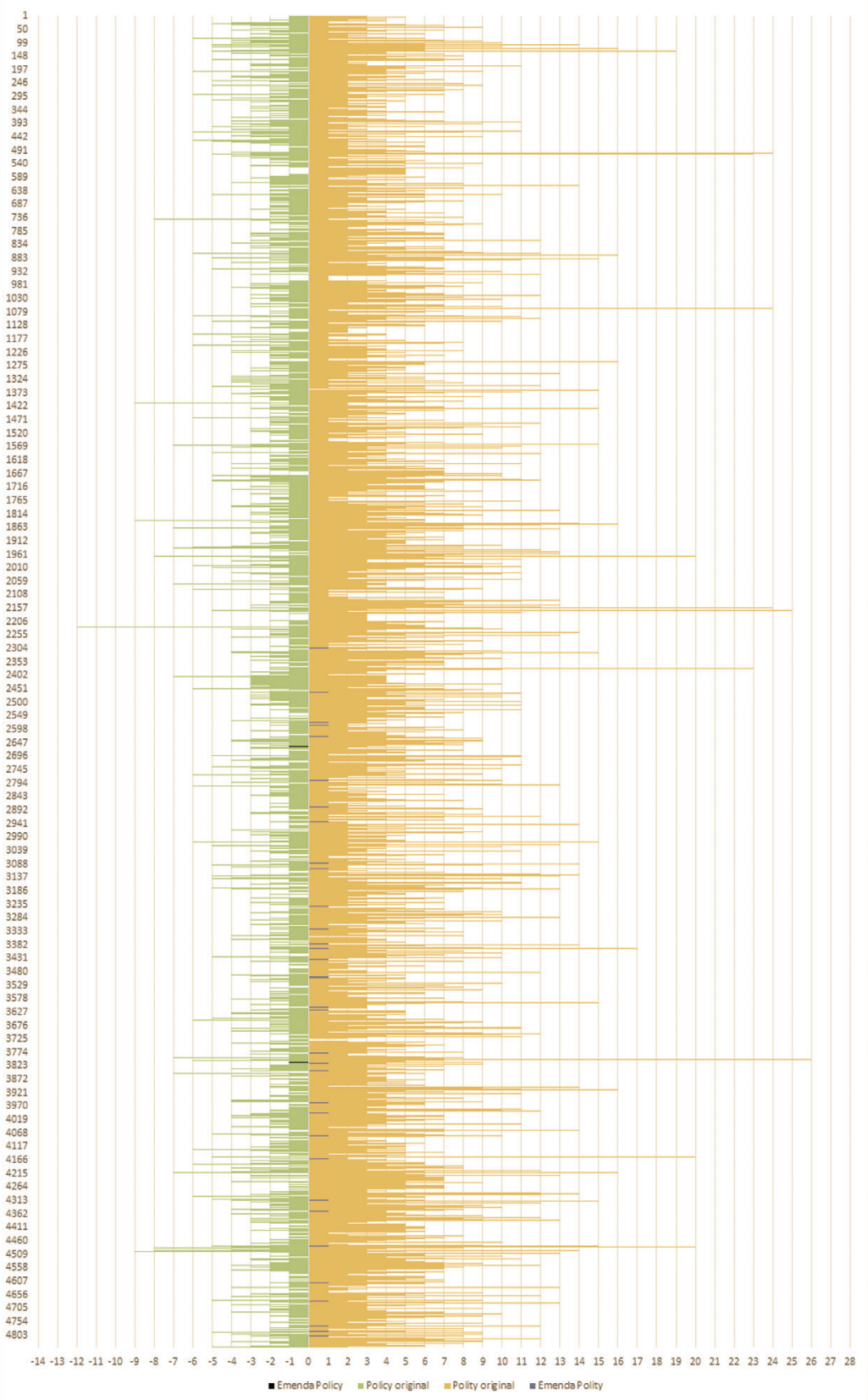

Fonte: Elaborado pelo autor. 
Considerando os dispositivos constitucionais individuais promulgados desde 1988, incluídos os da Constituição original (exceto ADCT e excluídos os que figuraram na forma de intervalos na ação) e os editados por emenda, quase a metade desse total (46\%) já foi invocada como fundamentação constitucional de ADI. Como se vê pelo gráfico 3, a dispersão é grande, o que sugere o extensivo uso que os atores têm feito do marco constitucional. Por outro lado, vale a pena olhar de perto alguns dos 24 dispositivos que foram citados mais de 100 vezes no universo de 4.848 ações. Eles revelam as quatro dimensões relevantes do acionamento do Supremo e de seu papel na política constitucional brasileira.

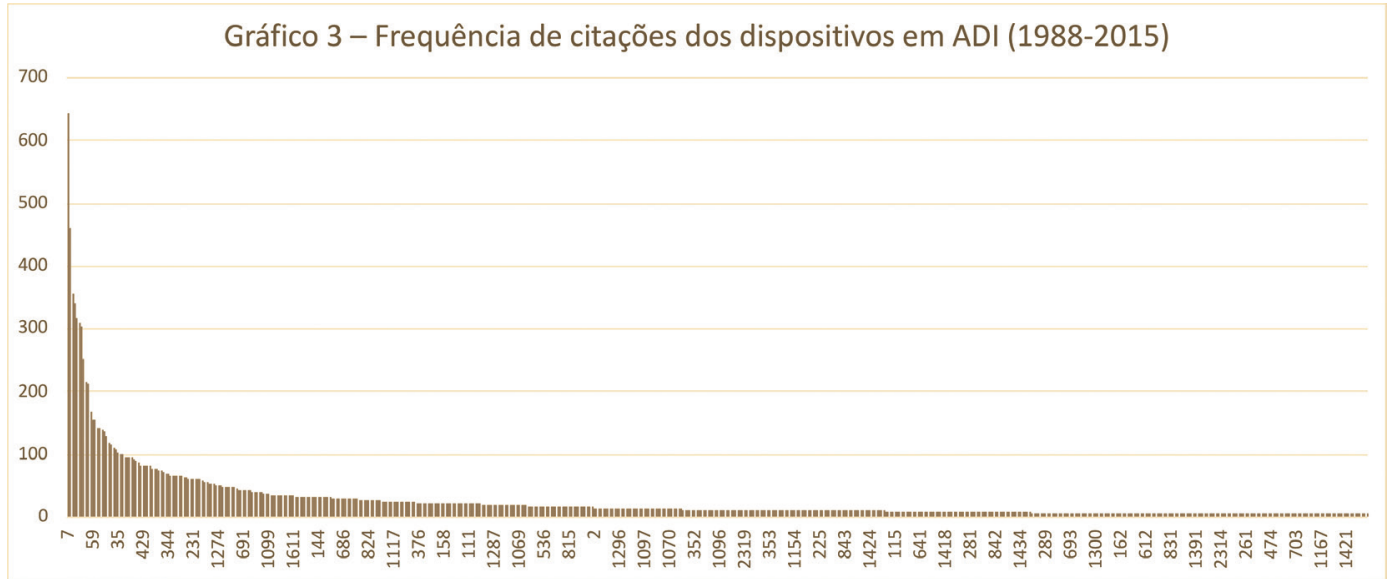

Fonte: Elaborado pelo autor.

(*) Por limite de visualização, não foram representados no gráfico os dispositivos com citações abaixo de 5 , que totalizam 731 dos 1.302 casos.

O dispositivo mais citado em fundamentação constitucional das ADI é o art. $2^{\circ}$ da Constituição (dispositivo 7 na base MAC): "São Poderes da União, independentes e harmônicos entre si, o Legislativo, o Executivo e o Judiciário.” Abre-alas do controle constitucional brasileiro, o art. $2^{\circ}$ aparece 644 vezes no universo das ADIs e representa, de fato, a primeira e mais importante dimensão da atividade do Supremo, pois diz respeito às relações horizontais entre poderes. $\mathrm{O}$ segundo dispositivo mais citado, com 460 ocorrências, é o art. 22 (de número 280 na base MAC): “Compete privativamente à União legislar sobre: I - direito civil, comercial, penal, processual, eleitoral, agrário, marítimo, aeronáutico, espacial e do trabalho;". Este, por sua vez, é representativo da segunda dimensão mais importante da atuação do Supremo, a 
de tribunal da Federação, responsável pelas relações verticais envolvendo a divisão de competências legislativas entre Estados e União. Ainda na dimensão federativa, o art. 25 - que abre o capítulo da Constituição dedicado aos Estados - é um dos mais citados, com 318 menções individuais, e o caput do art. 18 - que define a própria Federação - também está entre os mais invocados, com 137 citações diretas.

O terceiro dispositivo mais citado, representativo da terceira dimensão, com 356 ocorrências, diz respeito ao art. 37, II da Constituição, que trata da investidura em cargo ou emprego público por concurso público, ressalvadas as nomeações para cargo em comissão declarado em lei de livre nomeação e exoneração. Tal dispositivo, classificado como policy pela MAC por seu grau de especificidade, sinaliza para as disputas corporativas envolvendo carreiras públicas, na maioria das vezes jurídicas, como já apontado por Oliveira (2016) e reiterado por Oliveira e Argulhes (2021). Dentre os dispositivos mais citados, outro que se ocupa diretamente dos interesses envolvendo servidores públicos, com 212 aparições em ADIs, e originalmente classificado como policy, é o art. $61, \$ 1^{\circ}, \mathrm{II}, c$, que trata da iniciativa privativa do presidente da República de lei que trate do regime jurídico, provimento de cargos, estabilidade e aposentadoria de servidores públicos da União e Territórios, civis e militares. Outras alíneas do inciso II do art. 61 como $a, b$ e $e$, que tratam de grandes áreas de interesse do funcionalismo público reservadas à iniciativa privativa de lei do Executivo, também estão entre os mais citados em ADI. Além dos dispositivos vinculados ao art. 61, aparecem dois incisos do art. 37, o XIII, que trata da vedação à vinculação ou equiparação de vencimentos, para efeito de remuneração dos servidores públicos (com 167 menções), e o X, que estabelece que a revisão geral da remuneração dos servidores públicos, civis e militares, deve ser feita sempre na mesma data (com 139 menções). Em síntese, esses dispositivos são representativos da terceira dimensão que notabiliza o Supremo, a de tribunal dos interesses corporativos do serviço público.

Por fim, mas não menos importante, a quarta dimensão relevante aponta para o STF como um tribunal dos direitos fundamentais, o que não poderia faltar. O quarto dispositivo mais citado, com aparição em 341 ADIs, é o inciso LIV do art. $5^{\circ}$, segundo o qual ninguém será privado da liberdade ou de seus bens sem o devido processo legal. Outros incisos do art. $5^{\circ}$ também figuram entre os vinte mais citados, como o XXXVI (a lei não prejudicará o direito adquirido, o ato jurídico perfeito e a coisa julgada), o II (ninguém será obrigado a fazer ou deixar de fazer alguma coisa senão em virtude de lei), o XXXV (a lei não excluirá da apreciação 
do Poder Judiciário lesão ou ameaça a direito) e o LV (aos litigantes, em processo judicial ou administrativo, e aos acusados em geral são assegurados o contraditório e a ampla defesa, com os meios e recursos a ela inerentes).

É notável, portanto, como os quatro dispositivos mais citados em ADI, secundados por outros no topo do acionamento do controle constitucional, conformam a imagem, nessa ordem, de um tribunal das relações entre poderes, da Federação, dos interesses específicos constitucionalizados (especialmente das carreiras públicas) e dos direitos fundamentais. Todavia, a maioria dos dispositivos com citação acima de 100 é formada por regras de polity e não de policy. Afora o fato de que estamos tratando de $30,8 \%$ do total de citações, o predomínio desse tipo de dispositivo pode ser explicado pelo fato de que, ceteris paribus, uma regra de polity é condição necessária e suficiente para ingressar no STF, ao passo que uma regra de policy constitucionalizada, embora necessária, nem sempre é suficiente e muitas vezes carece de uma polity como abrealas. Por isso é necessário examinar o perfil do conjunto da distribuição, e não apenas dos dispositivos mais citados. É o que faremos adiante.

A tabela 2 compara os dispositivos de polity da Constituição original com os citados em ADI. Semelhanças e diferenças nas distribuições são igualmente notáveis. $\mathrm{O}$ acionamento do controle constitucional corresponde, em boa medida, ao perfil da Constituição. $\mathrm{O}$ achado dessa semelhança pode ser trivial, mas nunca havia sido demonstrado. Entretanto, há também diferenças, mas elas ocorrem igualmente onde era de se esperar: os dispositivos relacionados a direitos individuais de liberdade e participação política (tipo 2) são invocados pelas ADIs em proporção superior à do próprio texto constitucional, confirmando assim a natureza do mecanismo do controle constitucional e sua vocação clássica para a defesa das liberdades individuais, civis e políticas. Outros dispositivos que, combinados, superam a proporção em que figuram no texto constitucional são os relativos às definições de Estado Nação plus Regras do jogo. São justamente aqueles que presidem as relações entre União e estados no interior da Federação brasileira, afinal 2/3 das ADIs no período de 1988-2015, em média, recaíram sobre normas estaduais. 
Tabela 2 - Dispositivos de polity da CF 1988 e citados em ADI

\begin{tabular}{|c|c|c|c|c|}
\hline & \multicolumn{2}{|c|}{ Constituição 1988} & \multicolumn{2}{|c|}{ Dispositivos em ADIs } \\
\hline & $\mathbf{N}$ & $\%$ & $\mathbf{N}$ & $\%$ \\
\hline 1. Estado e Nação & 79 & 7,0 & 411 & 3,2 \\
\hline $\begin{array}{l}\text { 2. Direitos Individuais } \\
\text { Fundamentais }\end{array}$ & 94 & 8,3 & 2.362 & 18,2 \\
\hline 3. Regras do Jogo & 616 & 54,6 & 5.008 & 38,6 \\
\hline 4. Direitos Materiais & 64 & 5,7 & 641 & 4,9 \\
\hline $\begin{array}{l}\text { Duplo: Estado Nação + } \\
\text { Regras do Jogo }\end{array}$ & 161 & 14,3 & 3.412 & 26,3 \\
\hline $\begin{array}{l}\text { Duplo: Direitos Individuais } \\
\text { Fundamentais + Regras do } \\
\text { Jogo }\end{array}$ & 46 & 4,1 & 529 & 4,1 \\
\hline Outros dispositivos duplos & 59 & 5,2 & 585 & 4,5 \\
\hline $\begin{array}{l}\text { Outros dispositivos (triplos e } \\
\text { quádruplo) }\end{array}$ & 9 & 0,8 & 36 & 0,3 \\
\hline Total & 1.128 & 100 & 12.984 & 100 \\
\hline
\end{tabular}

Fonte: Elaborado, com números em destaque na última coluna, pelo autor. 


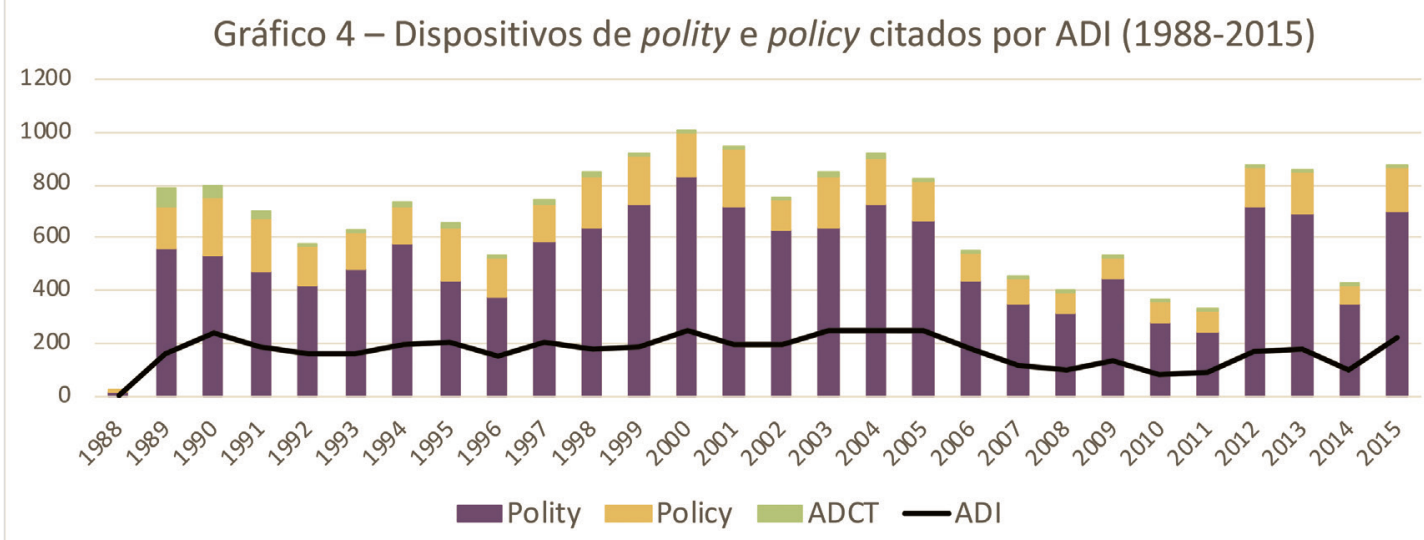

Fonte: Elaborado pelo autor.

Do universo de 4.848 ações, nada menos do que 47,4\% citaram pelo menos um dispositivo de policy. Em outras palavras, na quase metade das vezes em que o controle constitucional foi acionado, uma política pública constitucionalizada estava envolvida como fundamento constitucional da ação. O gráfico 4 apresenta a proporção de dispositivos polity/policy invocados por meio de ADIs, bem como a quantidade de ações apresentadas por ano.

Embora a proporção polity/policy permaneça relativamente constante ao longo do período, variações significativas são notadas no que diz respeito ao número absoluto de ações, com destaque para o declínio entre 2006 e 2011. A perda de interesse em movimentar o controle constitucional nesses anos ocorreu com três dos quatro atores tradicionalmente mais atuantes: os partidos políticos, que já vinham arrefecendo seu ímpeto desde a alternância no poder presidencial em 2003; os governadores e a Procuradoria-Geral da República. A queda geral só não foi mais acentuada porque as entidades civis (confederações sindicais e entidades de classe de âmbito nacional) mantiveram sua média histórica de 60 ações por ano, inclusive nesse período em que os demais diminuíram o ritmo. Outro dado importante diz respeito ao fato de que o declínio foi mais acentuado no caso de ADIs contra normas estaduais, enquanto as relativas a normas federais mantiveram mais ou menos seu patamar histórico.

Não é tarefa simples interpretar essas oscilações no acionamento do controle direto de constitucionalidade. Uma primeira hipótese é que elas decorrem da variação da agenda de interesses dos próprios atores institucionais e sociais legitimados a usar a ADI. De fato, não faz sentido supor que elas permaneçam constantes ao longo do tempo, seja para cada ator individual, seja no agregado de entes tão diversos entre 
si. Partidos que se alternam no poder, nos planos federal e estadual, do governo à oposição e vice-versa, tendem a mudar naturalmente de posição no que diz respeito ao acionamento do Tribunal, especialmente no que se refere à judicialização de políticas públicas. A Procuradoria-Geral da República, embora seja um órgão institucional, tem sua performance bastante afetada pelo perfil do ocupante do cargo - que pode mudar a cada dois anos, como também pode ser reconduzido a ele inúmeras vezes pelo presidente, como já ocorreu. Dependendo do contexto, a PGR pode muito bem diminuir sua atuação na provocação do controle constitucional para dar prioridade à persecução penal de altas autoridades com foro especial no STF, por exemplo. Seja como for, quem observar separadamente o número de ADIs promovidas anualmente pela PGR encontrará períodos de alta e de baixa muito bem demarcados.

Outra hipótese, nem sempre lembrada pelos analistas, é que leis e atos normativos precisam dar causa ao acionamento do controle, e, do mesmo modo que na hipótese anterior, não faz sentido supor que essas causas sejam constantes no tempo. Normas legais nem sempre são controversas e podem vir ao mundo de forma consensual, ou sustentadas por maiorias políticas tão amplas que não suscitarão oposição na forma de controle constitucional. Não sendo problemáticas, não acarretarão reações a posteriori. Por outro lado, as eventuais ofensas que venham a causar podem ter escopos e saliências tão diversos que suscitarão por parte dos atores afetados diferentes estratégias de litigância judicial, das quais o acionamento do controle abstrato é apenas uma delas. Outra hipótese deve considerar a origem da norma, se federal ou estadual, e os diplomas legais questionados. Qualquer conclusão que tenha pretensão teórica, baseada nos valores agregados, torna-se temerária, no mínimo, porque as normas questionadas podem ter origem no plano da União ou no plano de 27 unidades subnacionais, marcadas por realidades e conflitos políticos os mais diversos. Por sinal, quem examinar em detalhe as normas questionadas por ADI encontrará mais de 20 tipos de diplomas legais ou formais, para além da lei ordinária que estamos habituados a imaginar como padrão no controle constitucional. Muitas delas, é verdade, não são sequer examinadas pelo Tribunal, por não figurarem entre as hipóteses de revisão judicial abstrata.

É razoável considerar também que o ator legitimado e interessado observe a composição e a agenda do Tribunal antes de ingressar com pedidos, avaliando suas chances de êxito naquele determinado contexto, afetando assim o timing da reação contrária à norma editada. Aliás, diferentemente de outros países em que leis promulgadas só podem ser questionadas constitucionalmente até certo prazo desde a sua edição, no Brasil não há limites temporais e qualquer norma criada após 1988 pode ser objeto de ADI. Num universo de 4.751 ações apresentadas entre 1988 
e 2015 contra diplomas federais e estaduais editados de 1988 em diante, a mediana entre a promulgação da norma e o ingresso da ADI foi de 1 ano e a média foi de 3. Apenas $40 \%$ das ações foram apresentadas no mesmo ano de edição da norma. Assim, por exemplo, a hipótese baseada na ideia de que a oposição usa o controle constitucional para agir contra o governo tem como primeira lição de casa a tarefa de verificar se o acionamento se deu no mesmo ano em que a norma foi editada. Do contrário, governo e oposição podem ter invertido suas posições de um ano a outro, e o analista tomará gato por lebre. Inclusive, partidos no governo podem ingressar com ADI contra leis e atos normativos editados por governos anteriores, caso não consigam reformá-los por via legislativa.

Ainda no terreno da especulação sobre as práticas de acionamento do controle constitucional, pode ser que atores legitimados se coordenem no uso da prerrogativa, caso avaliem que uns têm mais chances de êxito do que outros. E, por fim, mas não menos importante, mudanças institucionais também podem afetar a série histórica como, por exemplo, a criação da $\mathrm{ADPF}$, cujo uso se intensifica coincidentemente com o declínio da ADI em 2008 e 2009. Em resumo, o controle constitucional por via de ação direta de inconstitucionalidade no Brasil se aproxima de uma figura poliédrica, multifacetada por atores legitimados e suas estratégias, por diferentes fontes de produção normativa e graus variados de controvérsia e saliência das políticas passíveis de controle, por questões de timing e de interações políticas, além de mudanças institucionais envolvendo o próprio Tribunal e as regras que presidem seu acesso e funcionamento.

A despeito desse sistema multifacetado, a tabela 3 indica que há razoável semelhança na fundamentação das ADIs por requerentes legitimados, quando classificamos as ações como polity ou policy, reduzindo a pluralidade de dispositivos citados com base na sua direção majoritária (em caso de empate na fundamentação, considerei a ADI como neutra). Ligeiras diferenças em relação à média ocorrem com as entidades civis (empresariais/profissionais) e assembleias legislativas, que tendem a fundamentar suas ações proporcionalmente mais em polity, ao passo que as entidades sindicais (trabalhistas) e a PGR recorrem mais a policy. Entretanto, essas variações também guardam relação com a origem das normas questionadas: ações contra normas estaduais estão proporcionalmente mais fundamentadas em policy do que polity. 
Tabela 3 - Polity e policy nas ações movidas por requerentes (1988-2015)

\begin{tabular}{|c|c|c|c|c|c|}
\hline & & Polity & Policy & Neutra & Total \\
\hline \multirow[t]{2}{*}{ Procurador-Geral da República } & $\mathrm{n}$ & 457 & 155 & 78 & 690 \\
\hline & $\%$ & $66,2 \%$ & $22,5 \%$ & $11,3 \%$ & $100,0 \%$ \\
\hline \multirow[t]{2}{*}{$\begin{array}{l}\text { Entidades civis (empresariais/ } \\
\text { profissionais) }\end{array}$} & $\mathrm{n}$ & 506 & 65 & 66 & 637 \\
\hline & $\%$ & $79,4 \%$ & $10,2 \%$ & $10,4 \%$ & $100,0 \%$ \\
\hline \multirow[t]{2}{*}{ Entidades civis (jurídicas) } & $\mathrm{n}$ & 165 & 38 & 11 & 214 \\
\hline & $\%$ & $77,1 \%$ & $17,8 \%$ & $5,1 \%$ & $100,0 \%$ \\
\hline \multirow[t]{2}{*}{ Entidades sindicais (trabalhistas) } & $\mathrm{n}$ & 95 & 30 & 21 & 146 \\
\hline & $\%$ & $65,1 \%$ & $20,5 \%$ & $14,4 \%$ & $100,0 \%$ \\
\hline \multirow[t]{2}{*}{ Outras entidades } & $\mathrm{n}$ & 30 & 6 & 3 & 39 \\
\hline & $\%$ & $76,9 \%$ & $15,4 \%$ & $7,7 \%$ & $100,0 \%$ \\
\hline \multirow[t]{2}{*}{ Governador } & $\mathrm{n}$ & 612 & 148 & 78 & 838 \\
\hline & $\%$ & $73,0 \%$ & $17,7 \%$ & $9,3 \%$ & $100,0 \%$ \\
\hline \multirow[t]{2}{*}{ Assembleia Legislativa } & $\mathrm{n}$ & 40 & 3 & 1 & 44 \\
\hline & $\%$ & $90,9 \%$ & $6,8 \%$ & $2,3 \%$ & $100,0 \%$ \\
\hline \multirow[t]{2}{*}{ Partido político } & $\mathrm{n}$ & 477 & 94 & 70 & 641 \\
\hline & $\%$ & $74,4 \%$ & $14,7 \%$ & $10,9 \%$ & $100,0 \%$ \\
\hline \multirow[t]{2}{*}{ Outros } & $\mathrm{n}$ & 7 & 0 & 0 & 7 \\
\hline & $\%$ & $100,0 \%$ & $0,0 \%$ & $0,0 \%$ & $100,0 \%$ \\
\hline \multirow[t]{2}{*}{ Total } & $\mathrm{n}$ & 2.389 & 539 & 328 & 3256 \\
\hline & $\%$ & $73,4 \%$ & $16,6 \%$ & $10,1 \%$ & $100,0 \%$ \\
\hline
\end{tabular}




\section{Gráfico 5. Política constitucional: CF-88, emendamento e controle constitucional}

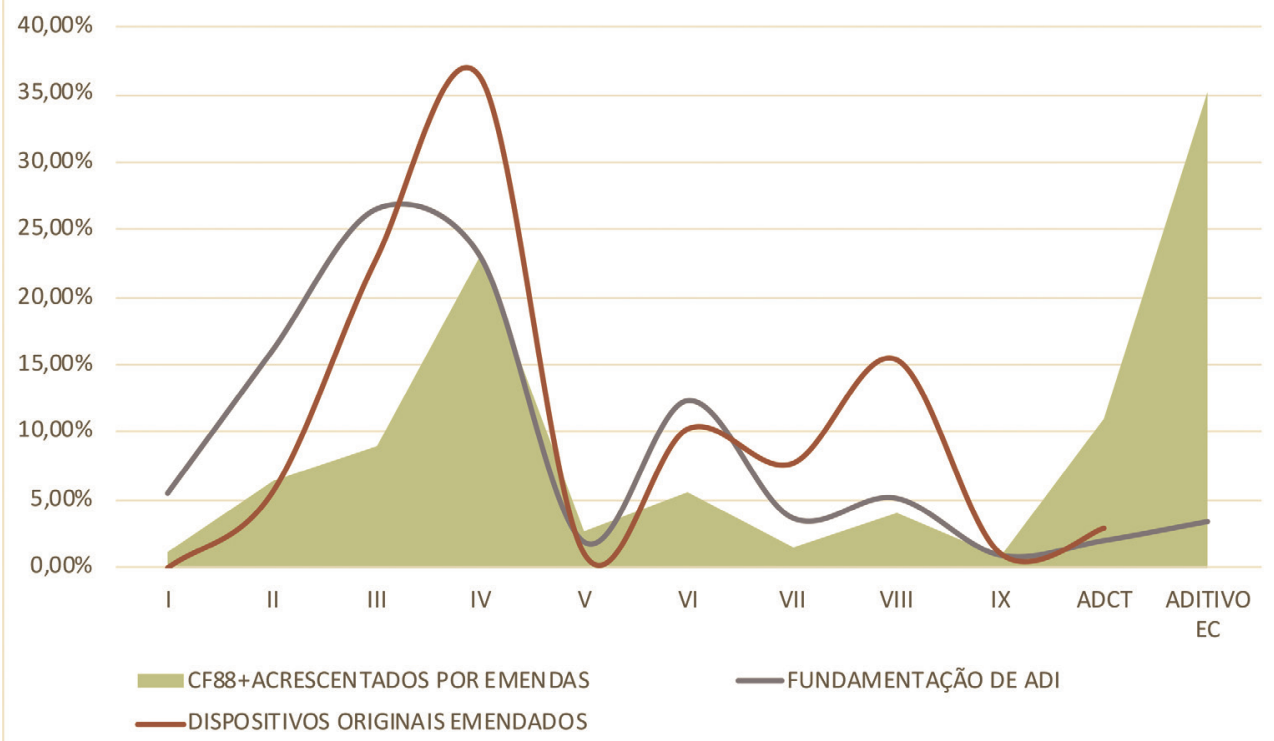

Fonte: Elaborado pelo autor.

Ográfico 5 sintetiza os achados dessa investigação sobre a política constitucional brasileira, e tudo parece estar no seu lugar. As linhas relativas à fundamentação de ADIs e ao emendamento constitucional tendem a acompanhar a topografia do texto constitucional original, mas com algumas diferenças importantes. A fundamentação de ADIs recorre proporcionalmente mais aos dispositivos dos títulos I, II e III da Constituição, que tratam dos princípios fundamentais, dos direitos e garantias e da organização do Estado. Nessa parte da Constituição residem os dispositivos abrealas do controle constitucional brasileiro e é natural que estejam sobrerepresentados. A partir daí, a fundamentação de ADIs acompanha o peso relativo dos títulos IV e V (organização dos poderes e defesa do Estado e instituições democráticas), para voltar a se destacar proporcionalmente no título VI (tributação e orçamento), mas aqui impulsionado pela maior frequência de dispositivos de policy no título. A fundamentação de ADI volta a acompanhar a silhueta da Carta nos títulos VII e VIII (ordem econômica e financeira e ordem social). O emendamento, por sua vez, poupou os títulos I e II, justamente aqueles que concentram maior proporção de polity, especialmente os direitos fundamentais. $\mathrm{O}$ emendamento começa a ganhar maior proporção nos títulos III e IV, por conta das emendas que reformaram dimensões 
importantes da estrutura do Estado e de um dos poderes, o Judiciário. No título VI, emendamento e ativação do controle constitucional coincidem em patamar elevado, indicando que se trata, de fato, do título mais disputado da Constituição, também por conta da grande presença de policy constitucionalizada. Por fim, embora o título da ordem social não tenha motivado tanto o controle constitucional, foi alvo de intenso reformismo via emenda, pois de todos os títulos é o que proporcionalmente encerra o maior número de políticas públicas constitucionalizadas.

Um dos achados mais importantes expressos pelo gráfico 5, entretanto, reside no fato de que os dispositivos acrescentados ao marco constitucional por meio de emendas (vide “ADITIVO EC” no gráfico 5) não tem servido significativamente de base para o acionamento do STF por meio de ADIs, pelo menos por ora. Esse resultado sugere que o emendamento constitucional e o controle constitucional guardam relativa independência entre si e, provavelmente, têm funcionado de modo complementar na experiência política brasileira. Ao prosseguir constitucionalizando principalmente policies, o Legislativo tem obtido êxito em superar pontos de veto - a Federação, o judiciário e, quando necessário, o próprio Executivo. Esse êxito pode se dar tanto por antecipação (emendas que visam evitar judicialização futura) quanto por dominância (emendas que visam corrigir decisões judiciais, fazendo prevalecer a vontade do legislador). O grau em que essas duas modalidades têm ocorrido e se combinado é uma questão empírica e será objeto de investigação futura.

\section{Conclusão}

Raros são os países nos quais a Constituição adquiriu tamanha centralidade como no caso brasileiro. Em muitos outros, o texto é reverenciado e de fato expressa o equilíbrio alcançado pelas forças políticas em disputa. Todavia, justamente por se limitar a definir o arcabouço estrutural da polity democrática, uma fina camada de poeira vai se depositando sobre ele, uma vez que não constitui alvo das pressões políticas cotidianas quando o regime está em equilíbrio. Nesses casos, conflitos e controvérsias se dão no plano da normatividade governamental e das disputas em torno de políticas públicas e, mesmo que haja algum controle constitucional ativo, não haverá necessariamente impacto sobre a estabilidade da Constituição. Em democracias constitucionais estáveis, sequer se consegue discernir se uma boa Constituição está assegurando a continuidade do regime democrático ou se o bom funcionamento da democracia está propiciando a longevidade constitucional. Causa e efeito se retroalimentam de tal forma que se tornam indissociáveis. 
Falando de modo mais específico, os estudos sobre estabilidade e mudança das Constituições têm se concentrado no efeito das regras de emendamento e na presença e atividade de revisão constitucional por tribunais, nem sempre integrando adequadamente essas duas dimensões institucionais nos modelos de explicação. A estes estudos também falta incorporar, como vimos neste artigo, a dimensão da demanda por mudanças constitucionais ou as razões que levam atores políticos a se engajarem na reforma ou substituição completa de textos constitucionais. Geralmente atribuído a fatores exógenos, o engajamento por tais mudanças começa finalmente a ser examinado com base em fatores endógenos às Constituições.

A Constituição brasileira de 1988 representa um caso especial no qual se combinaram fortes incentivos - derivados de suas características internas - e certa facilidade - derivada das regras - para sua revisão permanente. Este artigo reiterou como a constitucionalização de policy fez descer a Constituição de 1988 ao plano da política governamental, e como os atores políticos seguiram operando no plano constitucional nos anos seguintes, incorporando mais políticas ao texto, por meio do emendamento constante. No Brasil, governa-se por meio da Constituição, e este é um traço distintivo da democracia brasileira em perspectiva comparada. A falta de estabilidade de nosso texto não indica, portanto, uma polity democrática em crise, mas um conjunto de policies constitucionalizadas em permanente transformação.

Teorias baseadas em pontos de veto costumam considerar a Constituição como um deles, na medida em que representa um obstáculo importante para o exercício da vontade majoritária. No Brasil, as evidências apontam que a Constituição se transformou num instrumento de superação de pontos de veto institucionais, em que pese isso obrigue as maiorias políticas a se recomporem na forma de supermaiorias. Embora o poder Executivo tenha sido considerado o principal artífice dessas amplas coalizões no pós-1988, evidências apontam para um papel não menos relevante do Legislativo, que, por meio das emendas constitucionais, submete a Federação, o Judiciário e muitas vezes o próprio Presidente às suas preferências políticas.

Evidentemente, uma Constituição pródiga em políticas públicas constitucionalizadas e que não para de crescer representa forte estímulo à ativação do controle constitucional. Some-se a isso um sistema de judicial review descentralizado e bastante acessível a atores políticos, sociais e institucionais, e a política constitucional encontrará terreno para prosperar intensamente. Este artigo revelou a extensão em que a Carta de 1988 é acionada por aqueles que procuram o STF e demonstrou que há coincidência matemática das proporções polity/policy que marcam o perfil do acionamento e o perfil da Constituição. Constatou também o maior peso relativo 
dos direitos individuais fundamentais e das definições de Estado e Nação plus Regras do Jogo associadas na fundamentação das ADIs. Esses achados indicam como o STF combina, de fato, a clássica função contramajoritária com a de tribunal da Federação. De outro lado, confirmando o efeito esperado da constitucionalização de políticas públicas, cerca de metade das ADIs ajuizadas no STF conteve pelo menos um dispositivo de policy constitucionalizada. Verificou-se que isso é mais frequente quando a norma questionada é estadual, o que sugere que a política constitucional envolvendo a atuação do STF, juntamente com o emendamento frequente da Constituição, tem funcionado efetivamente como forma de governar a Federação. Por fim, embora seja necessária uma análise mais detalhada, evidenciou-se como os diferentes atores legitimados levam políticas públicas à apreciação do Tribunal, uns mais, outros menos. E, por vezes, são os interesses particulares de carreiras públicas que escalam o edifício constitucional.

Se Constituições se mantêm ao longo do tempo em grande medida graças aos mecanismos institucionais da regra de emendamento e do controle constitucional - que oferecem simultaneamente proteção e oportunidade de mudança -, no Brasil tais mecanismos não se limitam a essas funções clássicas, mas têm propiciado o crescimento constante da Constituição, a sua transformação em instrumento da governança, a inclusão do STF no governo da policy e a política constitucional em atividade permanente, na relação entre os Poderes e no interior da Federação. Tais características, somadas, desafiam o saber convencional do direito constitucional e da política comparada.

Na literatura especializada, esforços têm sido feitos no sentido de modelar as diferentes combinações envolvendo o grau de flexibilidade/rigidez das Constituições e a força/fraqueza da revisão judicial. Além disso, as relações entre os poderes têm sido pensadas na forma de jogos de delegação, mas também de antecipação, em que múltiplas rodadas podem envolver decisões por inconstitucionalidade de leis seguidas de emendamento constitucional, ou de emendamento preventivo para evitar a ingerência de tribunais nas políticas de governo. O Brasil oferece elementos nessas diversas direções, mas o que este texto também demonstrou é que não parece haver um conflito aberto entre o emendamento e o controle constitucional pelo STF. Esses dois mundos têm se portado de modo mais complementar do que antagônico, sob essa peculiar Constituição policy-oriented que criamos e alimentamos quase todos os dias. 


\section{Referências}

ANCKAR, Dag; KARVONEN, Lauri. Constitutional amendment methods in the democracies of the world. : NORDIC POLITICAL SCIENCE CONGRESS, 13., 2002, Aalborg, Denmark. [Papers]. Aalborg, Denmark: [Nordic Political Science Association], 2002.

ARANTES, Rogério B. Judiciário e política no Brasil. São Paulo: Idesp/Sumaré, Educ., 1997.

ARANTES, Rogério B. Constitutionalism, the expansion of Justice and the judicialization of politics in Brazil. : SIEDER, Rachel; SCHJOLDEN, Line; ANGELL, Alan (org.). The Judicialization of Politics in Latin America. New York: Palgrave Macmillan, 2005. p. 231-262.

ARANTES, Rogério B. Cortes constitucionais. In: AVRITZER, L. et al. (org.). Dimensões políticas da Justiça. Rio de Janeiro: Civilização Brasileira, 2013. p. 195-206.

ARANTES, Rogério B. Judiciário: entre a Justiça e a política. : AVELAR, Lucia; CINTRA, Antonio O. (org.). Sistema político brasileiro: uma introdução. 3. ed. Rio de Janeiro; São Paulo: F Konrad Adenauer; Ed. UNESP, 2015.

ARANTES, Rogério B.; ARGUELHES, Diego W. O estado da arte da pesquisa sobre o Supremo Tribunal Federal. : MAFEI, Rafael; FEFERBAUM, Marina (org.). Metodologia da pesquisa em Direito: técnicas e abordagens para elaboração de monografias, dissertações e teses. 7. ed. São Paulo: Saraiva, 2019. p. 437-450.

ARANTES, Rogério B.; COUTO, Cláudio G. A Constituição sem fim. In: DINIZ, Simone; PRAÇA, Sérgio (org.). Vinte anos de Constituição. São Paulo: Paulus, 2008. 62 p.

ARANTES, Rogério B.; COUTO, Cláudio G. Uma Constituição incomum. In: A constituição de 1988: passado e futuro. CARVALHO, M. A. R.; ARAUJO, C.; SIMÕES, J. A. (org). São Paulo: Hucitec, Anpocs, 2009.

ARANTES, Rogério B.; COUTO, Cláudio G. Construção democrática e modelos de Constituição. Dados, Rio de Janeiro, v. 53, n. 3, p. 545-585, 2010. Disponível em: https://doi. org/10.1590/S0011-52582010000300002. Acesso em: 16 maio 2021.

ARANTES, Rogério B.; COUTO, Cláudio G. Constitutionalizing policy: the Brazilian Constitution of 1988 and its impact on governance. In: NOLTE, Detlef; SCHILLINGVACAFLOR, Almut (org.). New constitutionalism in Latin America: promises and practices. 1. ed. Farnham, Burlington: Ashgate Publishing, 2012. p. 203-222.

ARANTES, Rogério B.; COUTO, Cláudio G. 1988-2018: trinta anos de constitucionalização permanente. In: MENEZES FILHO, Naércio; SOUSA, Andre Portela (org.). A Carta: para entender a Constituição brasileira. 1. ed. São Paulo: Todavia, 2019. p. 13-52.

ARANTES, Rogério B.; COUTO, Cláudio G. Constitutions and public policies. In: MENDES, Conrado H.; GARGARELLA, Roberto (ed.). The Oxford handbook of Constitutional law in Latin America. New York: Oxford University Press, 2020. 
ARAUJO, Mateus M. Comportamento estratégico no Supremo Tribunal Federal. 2017. 105 f. Tese (Doutorado em Ciência Política) - Faculdade de Filosofia e Ciências Humanas, Universidade Federal de Minas Gerais, Belo Horizonte, 2017. Disponível em: https://ppgcp. fafich.ufmg.br/defesas/300D.PDF. Acesso em: 16 maio 2021.

ARGUELHES, Diego W.; HARTMANN, Ivar. A. Timing control without docket control: how individual justices shape the Brazilian Supreme Court's agenda. Journal of Law and Courts, v. 5, n.1, p. 105-140, spring 2017. Disponível em: https://www.journals.uchicago.edu/doi/ pdf/10.1086/690195. Acesso em: 16 maio 2021.

ARGUELHES, Diego W.; RIBEIRO, Leandro M. (2018a)“The Court, it is I??: individual judicial powers in the Brazilian Supreme Court and their implications for constitutional theory”. Global Constitutionalism, v. 7, p. 236-262, 2018a. Disponível em: https:// edisciplinas.usp.br/pluginfile.php/4405320/mod_resource/content/1/Arguelhes\%20 Werneck\%20Molhano\%20Ribeiro\%20-\%20Court\%20it\%20is\%20I\%20individual_judicial_ powers_in_the_brazilian_supreme_court_and_their_implications\%20for_constitutional_ theory.pdf. Acesso em: 16 maio 2021.

ARGUELHES, Diego W.; RIBEIRO, Leandro M. "Ministrocracia?: O Supremo Tribunal individual e o processo democrático brasileiro". Novos Estudos Cebrap, v. 37, n.1, p. 13-32, jan./abr. 2018b. Disponível em: https://www.scielo.br/scielo.php?pid=S010133002018000100013\&script=sci_arttext. Acesso em: 16 maio 2021.

ARGUELHES, Diego W.; RIBEIRO, Leandro M. O Supremo individual: mecanismos de influência direta dos Ministros sobre o processo político. Direito, Estado e Sociedade, n. 46, p. 121-155, jan./jun. 2015. Disponível em: https://direitoestadosociedade.jur.puc-rio.br/ media/Artigo5_46.pdf. Acesso em: 16 maio 2021.

ARRETCHE, Marta. Quando instituições federativas fortalecem o governo central? Novos Estudos Cebrap, n. 95, p.39-57, mar. 2013. Disponível em: https://doi.org/10.1590/S010133002013000100003. Acesso em: 30 set. 2020.

ARRETCHE, Marta. Democracia, federalismo e centralização no Brasil. Rio de Janeiro: Editora FGV, Editora Fiocruz, 2012.

BOBBIO, Norberto. Liberalism and democracyLondon and New York: Verso, 1990.

BOGÉA, Daniel. Simbiose institucional: a interação institucional entre partidos políticos e o Supremo Tribunal Federal no presidencialismo brasileiro. 2018. Dissertação (Mestrado em Ciência Política) - Universidade de Brasília, 2018.

CANELLO, Julio. Judicializando a federação?: o Supremo Tribunal Federal e os atos normativos estaduais. 2016a. 291 f. Tese (Doutorado em Ciência Política) - Instituto de Estudos Sociais e Políticos, Universidade do Estado do Rio de Janeiro, 2016a.

CANELLO, Julio. Ações diretas no Supremo Tribunal Federal do Brasil (1988-2015). Harvard Dataverse, 2016b. v. 2. Disponível em: https://doi.org/10.7910/DVN/8WV3A4. Acesso em: 17 maio 2021. 
CASTRO, Marcus Faro de. O Supremo Tribunal Federal e a judicialização da política. Revista Brasileira de Ciências Sociais, v. 12, n. 34, p. 147-156, 1997.

COUTO, Cláudio G. Constituição, competição e políticas públicas. Lua Nova: revista de cultura e política, São Paulo, n. 65, p. 95-135, maio/ago. 2005. Disponível em: https://www. scielo.br/pdf/ln/n65/a05n65.pdf. Acesso em: 17 maio 2021.

COUTO, Cláudio G.; ARANTES, Rogério B. ¿Constitución o políticas públicas?: una evaluación de los años FHC. In: PALERMO, V. (ed.). Política brasileña contemporánea: de Collor a Lula en años de transformación, Buenos Aires: Instituto Torcuato di Tella y Editorial Siglo XXI, 2003. 647 p.

COUTO, Cláudio G.; ARANTES, Rogério B. Constituição, governo e democracia no Brasil. Revista Brasileira de Ciências Sociais, v. 21, n. 61, p. 41-62, 2006. Disponível em: https://www.scielo.br/j/rbcsoc/a/mGtBmjc9Xw5m99PDdqRzjdj/?format=pdf\&lang=pt. Acesso em: 17 maio 2021.

COUTO, Cláudio G.; ARANTES, Rogério B. Constitution, Government and Democracy in Brazil. World Political Science Review, v. 4, n. 2, Article 3, 2008. Disponível em: https://www. cepesp.io/uploads/2019/02/Couto_Arantes-Constitution-government-and-democracy-inBrazil.pdf. Acesso em: 17 maio 2021.

COUTO, Cláudio G.; ARANTES, Rogério B. Política constitucional e a centralidade da Constituição na democracia brasileira. ENCONTRO DA ABCP, 12., 2020. Anais. [s.1.], 2020. Área Temática: Instituições Políticas.

COUTO, Cláudio G.; LIMA, Giovanna de M. R. Continuidade de políticas públicas: a constitucionalização importa? Dados, v. 59, n. 4, p.1055-1089, out./dez. 2016. Disponível em: https://doi.org/10.1590/001152582016107. Acesso em: 30 set. 2020.

DESPOSATO, Scott; INGRAM, Matthew; LANNES, Osmar. Power, composition, and decision making: the behavioral consequences of institutional reform on Brazil's Supremo Tribunal Federal. Journal of Law, Economics, and Organization, 2014. Disponível em: https://papers.ssrn.com/sol3/papers.cfm?abstract_id=2553364. Acesso em: 17 maio 2021.

DIXON, Rosalind. Constitutional drafting and distrust. International Journal of Constitutional Law, v. 13, n. 4, p. 819-846, 2015. Disponível em: https://academic.oup.com/ icon/article/13/4/819/2450834?login=true. Acesso em: 17 maio 2021.

DIXON, Rosalind; HOLDEN, Richard. Constitutional amendment rules: the denominator problem. In: GINSBURG, Tom (ed.). Comparative constitutional design. Cambridge: Cambridge University Press, 2012. p. 195-218.

ELKINS, Zachary; GINSBURG, Tom; MELTON, James. The endurance of national constitutions. Cambridge: Cambridge University Press, 2009.

ELSTER, Jon. Ulysses and the sirens: studies in rationality and irrationality. Cambridge: Cambridge University Press, 1984. 193 p. 
ELSTER, Jon. Forces and mechanisms in constitution-making. Duke Law Review, v. 45, p. 364-96, 1995. Disponível em: https://core.ac.uk/download/pdf/187489266.pdf. Acesso em: 17 maio 2021.

ELSTER, Jon. Ulysses unbound: studies in rationality, precommitment, and constraints. Cambridge: Cambridge University Press, 2000.

ELSTER, Jon; SLAGSTAD, Rune (ed.). Constitutionalism and democracy. Cambridge: University of Cambridge Press; Norwegian University Press, 1988.

FERREIRA, Pedro Fernando Almeida Nery; MUELLER, Bernardo. How judges think in the Brazilian Supreme Court: estimating ideal points and identifying dimensions. Economia, v. 15, n. 3, p. 275-293, Sep./Dec. 2014. Disponível em: https://www.sciencedirect.com/science/ article/pii/S1517758014000253. Acesso em: 17 maio 2021.

FIGUEIREDO, Argelina; LIMONGI, Fernando. Executivo e legislativo na nova ordem constitucional. Rio de Janeiro: Editora FGV, 1999.

GINSBURG, Tom. Judicial review in new democracies: Constitutional Courts in Asian Cases. Cambridge: Cambridge University Press, 2003.

GINSBURG, Tom; ELKINS, Zachary and BLOUNT, Justin. Does the process of constitutionmaking matter? Annual Review of Law and Social Science, v. 5, p. 201-23, 2009. Disponível em: https://papers.ssrn.com/sol3/papers.cfm?abstract_id=1860392. Acesso em: 17 maio 2021.

GINSBURG, Tom; MELTON, James. "Does the constitutional amendment rule matter at all? Amendment cultures and the challenges of measuring amendment difficulty”. International Journal of Constitutional Law, v. 13, n. 3, p. 686-713, July 2015. Disponível em: https://doi. org/10.1093/icon/mov041. Acesso em: 7 jun. 2021.

GINSBURG, Tom; SIMPSER, Alberto (ed.). Constitutions in authoritarian regimes. Cambridge: Cambridge University Press, 2014.

GINSBURG, Tom; VERSTEEG, Mila. Why do countries adopt constitutional review? The Journal of Law, Economics, and Organization, v. 30, n. 3, p. 587-622, Aug. 2014. Disponível em: https://chicagounbound.uchicago.edu/cgi/viewcontent.cgi? article=5621\&context=journal_ articles. Acesso em: 17 maio 2021.

HARDIN, Russell. Liberalism, constitutionalism and democracy. New York: Oxford University Press, 2003.

HIRSCHL, Ran. Towards juristocracy: the origins and consequences of the new constitutionalism. Cambridge, MA: Harvard University Press, 2004.

HOLMES, Stephen. Precommitment and the paradox of democracy. In: ELSTER, Jon; SLAGSTAD, Rune (ed.). Constitutionalism and democracy. Cambridge: University of Cambridge Press; Norwegian University Press, 1988. 
KNIGHT, Jack. Institutionalizing constitutional interpretation. In: FEREJOHN, J.; RAKOVE, J; RILEY, J (ed.). Constitutional culture and democratic rule. Cambridge: Cambridge University Press, 2001.

KOERNER, Andrei; FREITAS, Lígia Barros de. "O Supremo na constituinte e a constituinte no Supremo”. Lua Nova, n.88, pp.141-184, 2013.

LIJPHART, Arend. Patterns of democracy: government forms and performance in thirty-six countries. New Haven: Yale University, 1999.

LORENZ, Astrid. How to measure constitutional rigidity: four concepts and two alternatives. Journal of Theoretical Politics, v. 17, n. 3, p. 339-361, 2005. Disponível em: https://www. researchgate.net/publication/249676387_How_to_Measure_Constitutional_Rigidity_Four_ Concepts_and_Two_Alternatives. Acesso em: 17 maio 2021.

LUTZ, Donald S. Toward a theory of constitutional amendment.The American Political Science Reviewv. 88, n. 2, p. 355-370, June 1994.

LUTZ, Donald S. Toward a theory of constitutional amendment. In: LEVINSON, Sanford (ed.). Responding to imperfection: the theory and practice of constitutional amendment. Princeton: Princeton University Press, 1995.

MADEIRA, Ligia M. STF como ator político no Brasil: o papel do Tribunal no julgamento de ações de políticas sociais entre 2003 e 2013. Revista Debates, Porto Alegre, v. 8, n. 3, p 5795, 2014. Disponível em: https://seer.ufrgs.br/debates/article/view/49506/32320. Acesso em: 17 maio 2021.

MARIANO SILVA, Jeferson. Jurisdição constitucional no Brasil (1966-2017). Harvard Dataverse, 2018a. v. 2. Disponível em: https://doi.org/10.7910/DVN/WWPYNC. Acesso em: 17 maio 2021.

MARIANO SILVA, Jeferson. Mapeando o Supremo: as posições dos ministros do STF na jurisdição constitucional (2012-2017). Novos Estudos Cebrap, v. 37, n. 1, p. 35-54, 2018b. Disponível em: https://www.scielo.br/scielo.php?script=sci_arttext\&pid=S0101-33002018000100035\&lng= en\&nrm=iso\&tlng=pt. Acesso em: 17 maio 2021.

MARTINS, R. Pontos de divergência: Supremo Tribunal Federal e comportamento judicial. 2018. 102 f. Tese (Doutorado em Ciência Política) - Faculdade de Filosofia, Letras e Ciências Humanas, Universidade de São Paulo, 2018. Disponível em: https:/www.teses.usp.br/teses/ disponiveis/8/8131/tde-06022019-131330/publico/2018_RodrigoMartins_VOrig.pdf. Acesso em: 17 maio 2021.

MELO, Marcus A. Hiperconstitucionalização e qualidade da democracia: mito e realidade. In: MELO, Carlos R; SÁEZ, Manuel A (org.). A democracia brasileira: balanço e perspectivas para o século 21. Belo Horizonte: UFMG, 2007. 488 p. (Série Humanitas) 
MELO, Marcus A. Mudança constitucional no Brasil: dos debates sobre regras de emendamento à “megapolítica”. Novos Estudos Cebrap, v. 97, p. 187-206, nov. 2013. Disponível em: https:// www.scielo.br/j/nec/a/FqDJVdq9cL7gqZmXMmyygdQ/?lang=pt. Acesso em: 17 maio 2021.

NEGRETTO, Gabriel. Making Constitutions. presidents, parties, and institutional choice in Latin America, Cambridge: Cambridge University Press, 2013.

NEGRETTO, Gabriel (ed.) Redrafting constitutions in democratic orders: theoretical and comparative perspectives. Cambridge: Cambridge University Press, 2020.

NEGRETTO, Gabriel. Toward a theory of formal constitutional change: mechanisms of constitutional adaptation in Latin America. In: NOLTE, Detlef; SCHILLING-VACAFLOR Almut (org.). New constitutionalism in Latin America: promises and practices. 1. ed. Farnham, Burlington: Ashgate Publishing, 2012. p. 51-72.

NOLTE, Detlef. Constitutional change in Latin America: power politics or symbolic politics? In: ECPR JOINT SESSIONS OF WORKSHOPS, 2008, Rennes. [Paper for presentation]. Rennes, 2008.

NUNES, Rodrigo. Politics without insurance: democratic competition and judicial reform in Brazil. Comparative Politics, v. 42, n. 3, p. 313-331, Apr. 2010. Disponível em: https:// www.researchgate.net/publication/233611878_Politics_Without_Insurance_Democratic_ Competition_and_Judicial_Reform_in_Brazil. Acesso em: 17 maio 2021.

OLIVEIRA, Cássio Santos Pinto. Entre poderes e políticas: o STF no Presidencialismo e sua jurisdição. 2018. 133 f. Dissertação (Mestrado em Ciência Política) - Faculdade de Filosofia, Letras e Ciências Humanas, Universidade de São Paulo, 2018. Disponível em: https://www.teses.usp.br/teses/disponiveis/8/8131/tde-24072019-173541/publico/2018_ CassioSantosPintoDeOliveira_VCorr.pdf. Acesso em: 17 maio 2021.

OLIVEIRA, Fabiana L. Justiça, profissionalismo e política: o STF e o controle da constitucionalidade das leis no Brasil. Rio de Janeiro: Editora FGV, 2011. 260 p Disponível em: https://bibliotecadigital.fgv.br/dspace/bitstream/handle/10438/10354/Justi\%C3\%A7a\%2C\%20 profissionalismo\%20e\%20pol\%C3\%ADtica.pdf?sequence=1\&isAllowed=y. Acesso em: 17 maio 2021.

OLIVEIRA, Fabiana L. Processo decisório no Supremo Tribunal Federal: coalizões e 'panelinhas'. Revista de Sociologia e Política (UFPR), v. 20, n. 44, p. 139-153, 2012. Disponível em: https://doi.org/10.1590/S0104-44782012000400011. Acesso em: 17 maio 2021.

OLIVEIRA, Fabiana L. Agenda Suprema - interesses em disputa no controle de constitucionalidade das leis no Brasil. Tempo Social, v. 28, n. 1, p. 105-133, 2016. Disponível em: https://doi.org/10.11606/0103-2070.ts.2016.106021. Acesso em: 7 jun. 2021.

OLIVEIRA, Fabiana L. Quando a corte se divide: coalizões majoritárias mínimas no Supremo Tribunal Federal. Revista Direito e Práxis, v. 8, n. 3, p. 1863-1908, 2017. Disponível em: https:// www.scielo.br/j/rdp/a/F5dbrvJ3YxPf9TpVQdZ5M5q/?lang=pt. Acesso em: 17 maio 2021. 
OLIVEIRA, Vanessa E. (org.). Judicialização de políticas públicas no Brasil. Rio de Janeiro: Editora Fiocruz, 2019. 332 p.

OLIVEIRA, Vanessa E. Poder Judiciário: árbitro dos conflitos constitucionais entre Estados e União. Lua Nova: Revista de Cultura e Política, n. 78, p. 223-250, 2009. Disponível em: https://www.scielo.br/pdf/ln/n78/a11n78.pdf. Acesso em: 17 maio 2021.

OLIVEIRA, Vanessa E. Judiciário e privatizações no Brasil: existe uma judicialização da política? Dados: Revista de Ciências Sociais, Rio de Janeiro, v. 48, n. 3, p. 550-587, 2005. Disponível em: https://www.scielo.br/pdf/dados/v48n3/a04v48n3.pdf. Acesso em: 17 maio 2021.

OLIVEIRA, Fabiana Luci; ARGUELHES, Diego Werneck. O Supremo Tribunal Federal e a mudança constitucional. Revista Brasileira de Ciências Sociais, v. 36, n. 105, dez. 2021. Disponível em: https://doi.org/10.1590/3610506/2020. Acesso em: 30 set. 2020.

POGREBINSCHI, Thamy. (2011) Judicialização ou representação?: política, direito e democracia no Brasil. Rio de Janeiro: Elsevier, 2011.

RÍOS-FIGUEROA, Julio; POZAS-LOYO, Andrea. Enacting constitutionalism: the origins of independent judicial institutions in Latin America. Comparative Politics, v. 42, n. 3, p. 293-311, Apr. 2010. Disponível em: https://www.researchgate.net/publication/233579322_ Enacting_Constitutionalism_The_Origins_of_Independent_Judicial_Institutions_in_Latin_ America. Acesso em: 17 maio 2021.

SOUZA, Celina. Regras e contexto: as reformas da Constituição de 1988. Dados: Revista de Ciências Sociais, Rio de Janeiro, v. 51, n. 4, p. 791-823, 2008. Disponível em: https://www. scielo.br/pdf/dados/v51n4/01.pdf. Acesso em: 17 maio 2021.

SOUZA, Celina. Instituições e mudanças: reformas da Constituição de 1988, federalismo e políticas públicas. In: HOCHMAN, Gilberto; FARIA, Carlos Aurélio P. de (org.). Federalismo e políticas públicas no Brasil. 1. ed. Rio de Janeiro: Ed. Fiocruz, 2013. p. 91-120.

TAYLOR, Matthew. Judging policy: courts and policy reform in democratic Brazil. Stanford: Stanford University Press, 2008.

TAYLOR, Matthew; DA ROS, Luciano. Os partidos dentro e fora do poder: a judicialização como resultado contingente da estratégia política. Dados: Revista de Ciências Sociais, Rio de Janeiro, v. 51, n. 4, 2008. Disponível em: https://www.scielo.br/pdf/dados/v51n4/02.pdf. Acesso em: 17 maio 2021.

TSEBELIS, George. The time inconsistency of long constitutions: evidence from the world. European Consortium for Political Research, v. 56, n. 4, p. 820-845, 2017.

TSEBELIS, George; NARDI, Dominic. A long Constitution is a (positively) bad Constitution: evidence from OECD Countries. British Journal of Political Science, v. 46, n. 2, p. 457-478, Apr. 2016. Disponível em: https://doi.org/10.1017/S0007123414000441. Acesso em: 7 jun. 2021. 
VIANNA, Luiz W.; BURGOS, Marcelo; SALLES, Paula. (2007) Dezessete anos de judicialização da política. Tempo social: Revista de Sociologia da USP, v. 19, n. 2, p. 39-85. Disponível em: https://www.scielo.br/pdf/ts/v19n2/a02v19n2.pdf. Acesso em: 17 maio 2021.

VIANNA, Luiz W.; CARVALHO, Maria A. R.; MELO, Manoel P. C.; BURGOS, Marcelo B. (1999). A judicialização da política e das relações sociais no Brasil. Rio de Janeiro: Revan, 1999.

VIEIRA, Oscar Vilhena. Supremocracia. Revista Direito GV, v. 4, n. 2, p. 441-464, 2008. Disponível em: https://www.scielo.br/pdf/rdgv/v4n2/a05v4n2.pdf. Acesso em: 17 maio 2021.

VIEIRA, Oscar Vilhena. Supremo Tribunal Federal: jurisprudência política. São Paulo: Editora Revista dos Tribunais, 1994. 152 p.

\section{Legislação citada}

BRASIL. [Constituição (1988)]. Constituição da República Federativa do Brasil de 1988. Brasília: Presidência da República, [2021]. Disponível em: https://www.planalto.gov.br/ ccivil_03/constituicao/constituicao.htm. Acesso em: 20 fev. 2021.

BRASIL. Emenda Constitucional no 3, de 17 de março de 1993. Altera os arts. 40, 42, 102, 103, 155, 156, 160, 167 da Constituição Federal. Brasília: Presidência da República, [1993]. Disponível em: https://www.planalto.gov.br/ccivil_03/constituicao/emendas/emc/emc03.htm. Acesso em: 17 maio 2021.

BRASIL. Emenda Constitucional no 45, de 30 de dezembro de 2004. Altera dispositivos dos arts. 5', 36, 52, 92, 93, 95, 98, 99, 102, 103, 104, 105, 107, 109, 111, 112, 114, 115, 125, 126, 127, 128, 129, 134 e 168 da Constituição Federal, e acrescenta os arts. 103-A, 103B, 111-A e 130-A, e dá outras providências. Brasília: Presidência da República, [2004]. Disponível em: https://www. planalto.gov.br/ccivil_03/constituicao/emendas/emc/emc45.htm. Acesso em: 17 maio 2021.

BRASIL. Lei no 9.868, de 10 de novembro de 1999. Dispõe sobre o processo e julgamento da ação direta de inconstitucionalidade e da ação declaratória de constitucionalidade perante o Supremo Tribunal Federal. Brasília: Presidência da República, [1999]. Disponível em: https:// www.planalto.gov.br/ccivil_03/leis/19868.htm. Acesso em: 17 maio 2021.

BRASIL. Lei no $\mathbf{9 . 8 8 2}$, de 10 de dezembro de 1999. Dispõe sobre o processo e julgamento da arguição de descumprimento de preceito fundamental, nos termos do $₫ 1$ o do art. 102 da Constituição Federal. Brasília: Presidência da República, [1999]. Disponível em: https://www. planalto.gov.br/ccivil_03/leis/19882.htm. Acesso em: 17 maio 2021. 